\title{
2014 ANKARA YEREL SEÇIMLERINDE PARTI LIDERI FAKTÖRÜNÜN SEÇMENIN OY VERME KARARINA ETKISi ${ }^{1}$
}

Kemal $\mathrm{AVCl}^{2}$

\section{ÖZET}

Demokratik toplumlarda siyasal yönetim işi siyasal partiler ile diğer siyasal organizasyonlar ve kişiler marifetiyle yapılır. Siyasal partiler ve diğer kişiler siyasal yönetime gelebilmek için seçmenin oyunu almak zorundadır. Seçimlerde seçmenin oyunu almanın birçok yolu ve yöntemi vardır. Seçmenin de ülkesini ve kendisini yönetecek parti veya kişilere oy vermesi için birçok değişik neden olabilmektedir. Seçmenin her hangi bir parti veya kişiye oy vermesinde; parti lideri, parti ideolojisi, partinin programı, partinin adayı, medya etkisi, kamuoyu araştırmaları gibi birçok sosyolojik, psikolojik, ekonomik, ideolojik ve başkaca nedenlerin rol oynadığı bilinmektedir. Bu çalışmada seçmenin oy verme nedenlerinden birisi olan lidere oy vermenin 2014 Ankara yerel seçimleri sonucuna etkisi ele alınmaktadır.

Bu çalışmada; 2014 Ankara yerel seçimlerinde seçmenin oy verme davranışlarını etkileyen faktörlerden en önemlisinin parti lideri faktörünün olduğu ve seçim sonuçlarını açık bir şekilde etkilediği belirlenmiştir.

Anahtar Kelimeler: Liderlik, siyasal parti liderliği, seçim, semen ve oy verme davranış1

\section{THE EFFECT OF PARTY LEADER FACTOR ON VOTING DECISION OF ELECTOR IN 2014 ANKARA LOCAL ELECTION}

\begin{abstract}
In the democratic societies political administration is carried out by political parties, other political organizations and persons. Political parties and other persons must get the votes of electors in order to reach at the political administration. There are many ways and methods of getting the votes of electors. There may be many different reasons behind voting of the electors for the parties or persons that will be in government. It is known that many sociological, psychological, economical and ideological reasons such as party leader, party ideology, party program, party candidate, media effect, public opinion research and others play role in voting of the electors for any party or person. This study considers the effect of voting for leader, as one of the reasons of electors voting, on the result of 2014 Ankara local election.

In this study it is found that the most important factor that influenced the voting behavior of elector was party leader factor and that this factor clearly influenced the election results in 2014 Ankara local election.
\end{abstract}

Keywords: Leadership, political party leadership, election, electors, voting behavior.

\footnotetext{
${ }^{1}$ Bu makaledeki araştırma verileri S.Ü. S.B.E. tarafından kabul edilen doktora tezinden alınmıştır.

${ }^{2}$ Dr., Enerji ve Tabii Kaynaklar Bakanlığ 1 , kavci@pigm.gov.tr.
} 


\section{Giriş}

Siyasal iletişim yöntemleri, başta Amerika Birleşik Devletleri olmak üzere bütün dünyada 1940'lı yıllardan itibaren, kitle iletişim araçlarındaki baş döndürücü teknolojik gelişmelerin de yardımı ile olağanüstü gelişmelere sahne olmaktadır. Amerika'nın özellikle başkanlık seçim kampanyalarında uyguladığı teknik ve yöntemlerle dünya'daki siyasal seçim kampanyası çalışmalarına öncülük ettiği görülmektedir. Literatürde; siyasal iletişim teknik, yöntem ve uygulamaları çerçevesinde "Amerikanvarileşme" adı ile ifade edilen bu yöntemler; siyasal reklam ve özellikle ticari pazarlamanın bütün deneyimlerinin siyasal alana uyarlanarak siyasal pazarlama mantığının oluşturulmasını amaçlamaktadır. Böylece, siyasal alana ticari bir bakış açısı getirilerek siyasal imajın ön plana çıkarılması sağlanmıştır. Özellikle Türkiye'de siyasal partiler, Amerika başta olmak üzere siyasal iletişim alanında değerlendirilmiş olan her türlü yeniliği kendi siyasal çalışmalarında denemekten geri kalmamaktadır. Bu yenilikler ve yasal düzenlemelerde de yer alan güçlü siyasal lider olgusu; lider üzerinden politika yapılmasının iyi sonuç almanın kolaylaştıracağı fikrini geliştirmiştir. Dolayısıyla, günümüz itibariyle siyasal kampanya çalışmalarında parti lideri faktörü, seçmenin rızasının kazanılmasında oy verme davranışlarını etkileyen en önemli değişken haline gelmiştir.

\section{Liderlik}

Liderlik konusu literatürde uğraşanların kişisel görüşlerine göre şekillenen birçok tanıma sahiptir. Bunlardan bir kaçının burada zikredilmesi liderliğin ne olduğunu ortaya koymaya yetecektir. Liderlik; "ortak bir amaca doğru grubun davranışlarını yönlendirmek için bireyin yapmış olduğu davranışların tümü” (Hempfill ve Cons'dan aktaran, Zel, 2011: 109) veya; “amaçları gerçekleştirmek için uğraşanları duruma göre uyarlayıcı, onların sorunlarını yanıtlayıcı bir rol" (Dubrin'den aktaran Zel, 2011: 110), veya “örgütlenmiş bir grubu, belli bir amac1 yerine getirmek maksadıyla insan davranışlarını etkileme faaliyeti” (Rauch ve Behling'den aktaran Zel, 2011:110) olarak tanımlanmıştır. Liderlik olgusunda, belli bir grup insan, belli bir amaç ve bu amaca grubu yönlendirecek liderin olması aranan 
2014 Ankara yerel seçimlerinde parti lideri faktörünün...

paydalardır. Bu paydaları içeren bir liderlik tanımı şöyle yapılabilir; "bir grup insanı belli amaçlar etrafında toplayabilme ve bu amaçları gerçekleştirebilmek için onları harekete geçirme, etkileyebilme bilgisi ve yeteneklerinin toplamıdır” (Zel, 2011: 110).

Liderlik; her dönemde, felsefe, psikoloji, yönetim bilimi, politika ve iletişimin konusu olmuştur. "Platon devlet adamında bilgi ve liyakat temelinde ele aldığ lideri, çevresini ve rakiplerini önderliği konusunda inandırabilen, farklı kişilik tiplerini bir araya getirebilen ve ahenkli birlikteliklerini sağlayabilen kişi olarak tanımlar" (Keskin, 2014: 155).

Yapılan araştırmalarda liderde; öz güven, tutarlı kişilik, samimiyet, canlılık, canlı ve yaratıcı zekâ, sağduyu, insanları anlama ve haberleşme gibi özelliklerin bulunması gerektiği tespit edilmiştir (Erzen, 2008: 68-69). Liderliği asabiyet kavramı ile açıklamaya çalışan ünlü İslam düşünürü İbni Haldun'a göre bir lider; merhamet ve mülayimlik, halkın kusurlarını araştırmama ve lüks hayattan uzak durma gibi özellikler taşımalıdır (Közleme, 2013: 243-244). Liderlik olgusuna "karizmatik liderlik" sıfatını kazandıran Max Weber; bu sıfatla; bir kişiyi olağan insanlardan ayıran ve onun aşkın, insanüstü, en azından bazı bakımlardan ayrıksı güçlere sahip sayılmasına yol açan özelliklerini anlatmaktadır. Bu özellikler sıradan insanlarda bulunmaz; çünkü bunlar ilahi kaynaklıdır. Bir kişi bu özelliklere sahip olduğu zaman karizmatik lider sayılır, karizmatik liderlik olağanüstü kriz zamanlarında ortaya çıkar (Közleme, 2013: 47-48; Keskin, 2014: 141).

Eski çağlardan günümüze kadar, liderlikle ilgili çeşitli teorilerin ileri sürüldüğü, kimi düşünürlerin liderliğin doğuştan gelen bir yetenek, kimilerinin de sosyalleşme sürecinde sonradan kazanılıp geliştirilen bir beceri olarak değerlendirdiği bilinmektedir. Buna göre klasik bir bakış açısıyla yapılmış olan en eski sınıflandırmaya göre liderlik teorilerini; özellik-nitelik, davranış ve durumsallık olmak üzere üç ana başlık altında toplamak mümkündür ( Zel, 2011: 114-162; Dinçer ve Bitirim, 2007: 66). Aslında liderlik teorilerine girerken; "liderliğin tek bir kişilik özellik ya da yetkinlikle açıklanamayacak kadar karmaşık, çok yönlü ve çok renkli bir olgu olduğunu da bilmek gerekir" (Barutçugil, 2014: 13). 


\section{Liderlik Teorileri}

3.1 Özellik ve nitelik teorileri: $\mathrm{Bu}$ yaklaşım; eski yunandan Sokrates'in liderde bulunması gereken özellikleri tanımlamasından başlayarak 1940’lı yıllara kadar geçen sürede liderliğe getirilen yaklaşımları kapsamaktadır. $\mathrm{Bu}$ teori liderliği, kişinin farklı psikolojik ve fizyolojik özellikleri ile açıklamaktadır. Bu özellikler genellikle; zekâ, yöneticilik yeteneği, girişenlik, kendine güven, statü, başarı, kararlılık, dinamizm ve gerçekçiliktir (Barutçugil, 2014: 30-42). Amerika'da yapılan bir araştırmada; lider olması gereken kişide hangi özelliklerin bulunması gerektiği konusunda 1500 civarında nitelikli yöneticiye sorulmuş ve 225 çeşitten fazla kişilik ve karakter özelliği ortaya çıkmıştır. Bu özellikler 15 kategori altında toplanmıştır. Bunlardan ilk üç kategorinin içeriği şöyle oluşmuştur; 1) dürüst, doğruyu söyleyen, güvenilir, karakterli ve inançl1, 2) rekabetçi, yetenekli ve üretken, 3) teşvik edici, yönlendirici ve kararlı. Yine Santa Clara Üniversitesi'nde 2600 denekle liderde bulunması geren kişilik özellikleriyle ilgili yapılan bir başka araştırmada; ilk beş özellik; dürüstlük \% 83, yetenekli $\% 67$, geleceği gören $\% 62$, teşvik edici $\% 58$ ve zeki \% 43 olarak gerçekleşmiştir (Kouzes'den aktaran Zel, 2011: 116-117). Neticede psikolojik ve fizyolojik kişilik kaynaklı liderlik konusunda çok sayıda çeşitli görüş ve çalışmaların olması doğaldır. Çünkü "liderlik tek bir kişilik özellik ya da yetkinlikle açıklanamayacak kadar, karmaşık, çok yönlü ve çok renkli bir olgudur” (Barutçugil, 2014: 13).

3.2 Davranışsal teori: Bu teori genellikle Amerika'da Ohio Üniversitesi ve Michigan Üniversitesi tarafından çalışılmıştır. Bu teorinin temelde iki liderlik tipinden yola çıkış noktası bulunmaktadır. Bunlar; göreve yönelmiş otokratik lider ve insana yönelmiş demokratik liderdir (Barutçugil, 2014: 32; Zel, 2011:125; Aktan vd., 2014: 60-67). Ohio Üniversitesi'nde 1945'l1 yıllarda başlayan askeri ve sivil çok sayıda yöneticinin üzerinde yapılan çalışmalarla amaç genelde; liderlik davranışlarının belirlenerek bunların organizasyonun amaçlarına ulaşmada ne derece önemli olduğunu sorgulamaya dayanmaktadır. Yapılan çalışmalarda; 1800 civarında lider davranış biçimi tespit edilmiş ve bu davranış biçimleri 150 soru altında toplanarak "Liderlik Davranışı Tanımlama Anketi” (Leadership Behavior Description 
2014 Ankara yerel seçimlerinde parti lideri faktörünün...

Questionnaire) oluşturulmuştur. Çalışmada; bir taraftan, bölgedeki tüm kamu, askeri, özel, sivil ve ticari sektörlerdeki yöneticilerin zamanlarını ilişkilerde nasıl kullandıkları ile sorumluluk ve otorite düzeyleri incelenirken, bir taraftan da vatandaşa (izleyici) liderlerin davranış biçimleri ile ilgili sorular yöneltilmiştir. Neticede çalışmada lider davranışlarının iki ayrı boyutta toplandığı tespit edilmiştir. Bunlar; yapıyı harekete geçirme (initiating structure) ve bireyi önemsemedir (consideration) (Yukl'den aktaran Zel, 2011: 125). Yapıyı ele geçirme; liderin kendi görevi ya da grubun görevleri ile ilgili olarak işi ve amaçları tanımlamaya, şekillendirmeye ve harekete geçirmeye yönelmiş faaliyetler olarak ifade edilmektedir. Bireyi önemseme ise; kişilerarası ilişkilerde karşılıklı güven ve karşılıklı ve eşit şartlarda iletişim ve astların fikirlerine saygı, önem verme duygusal yanlarının hesaba katıldığı faaliyetleri oluşturmaktadır.

Ohio araştırmaları ile aynı döneme denk gelen Rensis Likert başkanlığında yapılan Michigan Üniversitesi liderlik araştırmalarında; belli sayıda başarılı ve başarısız grupları inceleyerek, verimlilik, iş tatmini, personel devir hızı, devamsızlık, şikayetler, maliyet ve motivasyon gibi kriterler ile grubun verimliliğine katkıda bulunan faktörler tespit edilmeye çalışılmıştır. Bu çalışmalarda iş ve insan odaklı iki tip lider tespit edilmiştir. İş odaklı lider işin yapılıp yapılmamasına, başarılmasına ve bu minvalde kontrole önem veren disiplinli ve cezalandırıcı, otoritesini makamından alan lider tiplerini oluşturmaktadır. İnsan odaklı lider tipinde ise; izleyenleri ya da astları ile insani ilişkileri ön plana çıkaran, çalışanların gereksinimlerini kişisel gelişimlerini, mutlu olmalarına önem veren, grup çalışmalarına ağırlık veren ve iş birliği yapan özellikler tespit edilmiştir (Aktan vd., 2014: 62; Barutçugil, 2014: 3040; Zel, 2011: 128-138).

Michigan Ekolü'nün çalışmalarında; “en üretken gruplar; liderleri üretim merkezli olanlardan çok, çalışan birey merkezli olanlardır. En etkin lider ise; astları ile destekleyici destek kuranlar, grup kararı mekanizmasını çalıştıranlar ve izleyicilerini yüksek performans hedefleri oluşturmaya ve bunların başarılmasına teşvik edenlerdir” (Şimşek vd., 2001: 175). 
2014 Ankara yerel seçimlerinde parti lideri faktörünün...

Davranışlara dayalı liderlik teorisinde başlıca dört model bulunmaktadır. Bunlar; X ve Y teorileri, Dört Sistem Modeli, Liderlik Tarzları Doğrusu ve Yönetim Kafesleri Analizi'dir (Barutçugil, 2014: 32-40).

3.3 Durumsal liderlik yaklaşımı: $\mathrm{Bu}$ yaklaşım liderliği; insanlar arası ilişkiler yönelmiş ve göreve yönelmiş lider olmak üzere iki boyutta değerlendirmektedir. Yapılan araştırmalar bazı durumlarda insanlar arası ilişkilere yönelmiş demokratik liderliğin başarılı olduğunu bazı durumlarda da göreve yönelmiş otoriter yönetim anlayışının başarılı olduğunu ortaya koymuştur. Sonuçta liderlikte başarının durumlara göre değişebileceğini göstermiştir. Bu yaklaşımı temsil eden iki model bulunmaktadır. Bunlar; Liderlik Etkinliğinde Durumsallık Modeli ve Etkin Liderlik Tarzı Eğrisi modelleridir.

Liderlik Etkinliğinde Durumsallık Modeli: Bu modele göre; bazı durumlarda demokratik liderlik tarzının, bazı durumlarda göreve yönelmiş liderlik tarzının başarılı olduğu savunulmaktadır. Yani liderlik durumsal bir nitelik taşıdığı varsayılmaktadır. Yapılan çalışmalarda hangi liderlik tarzının hangi durumlara uygun olduğu ortaya konmaya çalış1lmış ve üç temel değişken tespit edilmiştir. Bunların birincisi; lider ve izleyici arasındaki ilişki, ikincisi; görevin yapısal özellikleri ve üçüncüsü; liderin sahip olduğu pozisyonun ona sağladığ1 güç’tür. Bu değişkenlerin çeşitli bileşimlerine göre farklı durum ve koşullarda liderin başarısı için benimsenecek tarzlar değişebilir. Burada önemli olan lider faktörünün yanında iş özellikleri, çevre faktörleri ve izleyici nitelikleri ve olgunluk düzeyleri dikkate alınmasidir.

Etkin liderlik tarzı eğrisi modeli: $\mathrm{Bu}$ model yönetim kafesleri analizine çalışanların özelliklerine yani olgunluk düzeylerine bir tür ilave yaparak yöneticinin farklı yönetim becerilerini nasıl ve ne zaman kullanacağını ortaya koymak için geliştirilmiş bir modeldir. Bu modelde; çalışanların olgunluk düzeyleri farklılık gösterir. Bu düzeyleri belirleyen değişkenler; yetenek ve eğitim düzeyi, güven duygusu ve istekliliktir. Lider bu değişkenlerden yola çıkarak çalışanların olgunluk 
2014 Ankara yerel seçimlerinde parti lideri faktörünün...

düzeylerine göre tutumunu ve tarzını belirleyecektir. Bu tarzlar; söyleme, satma, paylaşma ve devretme olarak belirlenmiştir.

\section{Siyasal Liderlik}

Siyasal yönetim anlayışı ne olursa olsun dünyadaki tüm toplumlarda kamusal işler, yani toplum adına yönetilmesi ve yapılması gereken işler, toplumların benimsediği genel usul ve yöntemlerin düzenlendiği siyasal yetkiler çerçevesinde yönetilerek yapılmaktadır. İşin içinde yönetim olduğuna göre burada bu işlerin bir yönetici marifetiyle yapıldığı da bilinmektedir. Kamusal işılerin görülmesi maksadıyla hizmet alımını demokratik yönetim biçimi olarak tercih etmiş toplumlarda bu işler siyasal organizasyonlar (parti) veya siyasal kişiler marifetiyle yürütülmektedir. Siyaset burada bir yönetim sanatı ve belirleyici rol olarak devreye girmektedir. $\mathrm{Bu}$ manada; siyaset de liderlerle yönetilmektedir. Liderler en küçük topluluğu yöneten kişiler olmakla birlikte ülkeleri de yöneten siyasi kişiliklerdir. "Siyasi kişilikleri ile topluluklara yön veren, fikirleriyle toplulukları o fikirler altında toplayan siyasal liderler, siyasi oluşumların vazgeçilmez isimleridir. Özellikle ülkemiz siyasi tarihinde siyasal liderlerin başında bulundukları partilerden daha baskın olabildiklerini ve seçmeni etkileme sürecinde büyük bir etken olduklarını söyleyebiliriz" (Akay, 2011: 81).

“Tarihin her döneminde var olan liderlik kitle iletişiminin gelişimiyle paralellik gösterir. Siyaset ve toplumun değiştiği ortamlarda liderler ve takipçileri yani seçmenleri arasında ilişkiler de değişim göstermiştir. Liderlik ve seçmen ilişkisi ise; doğru kurgulanmış bir kitle iletişim sistemi ile seçimlere ve liderin başarısına bağlıdır" (Kaid ve Bacha: 2008: 601-602).

Demokratik toplumlarda siyasal partiler; devlet aygıtını yönetebilmek ve bu gücü taraftarlarının lehine olacak şekilde kullanmak için, temsil etmede en önemli siyasal sembolik kurumlardır. Bütün kurumsal organizasyonların bir yönetim tarzı ve yöneticisinin olduğu gibi siyasal partiler de bir organizasyondur ve bunların kendi tarzlarına göre bir yönetim biçimi ve yöneticileri vardır. Siyasal organizasyonlarda yönetim işi en stratejik iştir ve partinin genel başkanı marifetiyle yürütülür. 
2014 Ankara yerel seçimlerinde parti lideri faktörünün...

Siyasal partilerde genel başkanlar siyasal kültür açısından "lider" olarak algılanır ve liderlik nosyonuna, yöneticilikten farklı anlamlar ve beklentiler yüklendiği bilinmektedir.

Halk tarafindan beğenilen iyi bir parti liderinin en önemli özellikleri; ileri görüşlülüğü, güvenirliği ve inanırlığı, ahlaki karakteri, bilgi birikimi, siyaset tecrübesi, konuşma tarzı ve ikna yeteneği, öğrenim durumu ve söylemleri olarak siralanabilir.

Siyasal anlamda liderlik yeni siyaset biçiminin en önemli unsuru olarak ön plana çıkmaktadır. Y1ldız (2002: 88; 2012: 128)'a göre bu durum;

"Partilerin merkeze yı̆̆ılması" olarak ifade edilmekte ve partilerin bir birlerine benzemeleri ile medyanın öneminin ve etkinliğinin toplumsal hayatta artmasına bağlı olarak liderlik olgusu ön plana çıkarılmıştır. Seçmen bireyin diğer tüketim alışkanlıklarında birbirine benzer ürünlerden bir şekilde farkına göre tercih edebiliyor olması, birbirine benzeyen ve merkeze yığılan partiler arasında da siyasal tercihini yaparken, “liderlik farkını” göz önünde bulunduracakları doğal kabul edilmektedir.

Siyasal yaşamda parti liderlerinin ve dolayısıyla lider imajlarının en önemli unsur olarak ortaya çıkmasının nedenleri şöyle değerlendirilmektedir (Yıldız, 2002: 81-207);

1) Parti kimliği ve parti bağları: Oy verme davranışı açısından parti kimliği önemli bir etmen olmasına karşılık, parti liderinin olağanüstü yetkileri, parti kimliği ve kültürünün lider imajı üzerinden kurgulanması ve başkaca sebeplerden dolayı seçmenlerin partili olma ve parti bağlarının zayıflamasına neden olmakta ve parti liderinin imajı ve partiyi temsil etme yetkinliği ile üstünlüğü konularının medya tarafından da işlenmesi ile ön planda tutulmaktadır. Böylece Jamieson'ın parti lideri faktörünün seçmenin oy verme davranışında neden çok önemli olduğuna dair şu görüşü konumuza açıklık getirmektedir (Aktaran Yıldız, 2002: 88); "Seçmenler verilen sözlerin ardından bir siyasetçinin dürüst, bilgili, ilkeli ve bir ulusu yönetmek için gereken karaktere sahip olup olmadığının ipuçlarını aramaktadır. Şimdilerde seçmen kararlarında siyaset adamının karakteri ve konular üzerinde duruşu, parti kimliğinden daha merkezi bir role sahiptir” Kışlalı da (1987: 363) sandık başına 
giden seçmeni; "güvenlik isteği”, "sayınlık isteği”, "duygusal bağlllık" ve "dinsel ve siyasal inançların” etkilediğine değinmektedir.

2) Partilerin benzerliği ve kurumsallaşma krizi: Günümüzde siyasal sistem içinde bütün siyasal partilerin ülke sorunları ve gündemdeki konularla ilgili ürettikleri politikalar birbirine benzemektedir. Dolayısıyla partilerin hepsi merkezde toplanarak benzeşmektedir. Siyasal partiler ortak paydaya dayalı aynı söylemlerin kısır döngüsünden kurtulup, farklılaşan siyasal toplumsal sorunlara ayırt edici üslupta politikalar geliştiremedikleri için, seçmenin partili olma bağı zayıflamış ve böylece "yüzer-gezer" veya "kararsız" seçmen tipi artmıştır. Bu seçmen tipinde imaj unsuru ön plana çıkarılmış lider unsurunu algılama ve lidere oy verme kararını güçlendirmiştir.

3) Parti içi demokrasi sorunu: Parti içi demokrasilerin işlemediği siyasal sistemlerde liderlerin ön plana çıkması, zayıf kalan parti temsil görevini parti lideri üstlenmektedir. Özellikle milletvekili adaylarının belirlenmesi sürecinin parti üyeleri tarafından seçilmesi yerine, bu yetkinin yasalarla parti tüzüklerinde düzenlenmesine yer verilmesine, partilerin de bu yetkiyi lider ve onun çevresinin kullanacağı şekilde düzenleme eğiliminde olmaları parti lideri olgusunu güçlendirmektedir.

1983 yılında yürürlüğe giren Siyasi partiler Kanunu'nun 37. maddesinde belirtilen aday belirlemede ön seçimi zorunlu kılan şekli 1986 yılında değiştirilerek aday belirleme de uygulanacak yöntemi parti tüzüklerine bırakılmıştır. Hiçbir parti tüzüğü parti içi demokrasiyi ön plana çıkarmamakta aksine lideri ön plana çıkarmaktadır (Akıncı ve Akın, 2013:336 ).

4) Kitle iletişim araçları ve "Yıldız (Star) Sistemi": Günümüzde kitle iletişim araçları siyasal imaj yapıcı fonksiyonu bir çeşit görev edinmiştir. Özellikle görsel medya başta olma üzere ve diğer iletişim araçları siyasal imajın oluşturulmasında ve izleyici seçmen bireye doğrudan taşınmasında, böylece bireyin bilinç dünyasında siyasal imajlar hakkında bir fikrin şekillenmesinde doğrudan rol almaktadır.

Tarihsel gelişim sürecinin her düzey ve aşamasında siyaset, kendini görünür kılabilmek, bulunduğu konumu güçlendirmek, egemenliğini pekiştirmek için, iletişime sürekli bir biçimde gereksinim duymuştur (Ekinci, 2014: 9). 
2014 Ankara yerel seçimlerinde parti lideri faktörünün...

5) Siyasal süreçteki dönüşüm: Özellikle 1980'li y1llardan itibaren siyaset yapma anlayışlarındaki kalıpların kırılması, yeni, çoklu ve renkli iletişim kanallarının doğması ve bunların siyasal alanla yakın ilişki içinde olması, siyaset yapma faaliyetlerinin Amerikanvarileşmesine neden olmuştur. Çok uluslu ticaret anlayışının bir yansıması ve teknolojik dayatması olarak siyasal pazarlama anlayışının siyaset dünyasında ilgi görmesi, siyasal parti liderlerinin hem parti içinde hem de seçmen nezdindeki konumunu ve imajını güçlendirmiştir. Nitekim Yıldız'ın yaklaşımı ile (2002: 101) Osmanlı'dan miras olarak kalan "tek adam” mantığı ile liderlerin parti yönetimindeki baskınlığı, kitle iletişim araçlarının işleyişindeki sorunlar ve parti bağlarının zayıflaması gibi nedenlerle oy verme davranışında lidere odaklanmaya neden olmuştur.

Özellikle 90'lı yıllar Türkiye'de siyasetin tipik Amerikanvarileşmesinin yaşandığı yıllardır. Bu yıllardan günümüze değin uzanan siyasal yaşam serüveninde lider ve imaj unsuru ön plana çıkmıştır. Bu durum partilerin seçim kampanyalarında kullandıkları görsellere yansımış ve daha ziyade parti liderinin fotoğraflarının (görsellerinin) kullanıldığı imaj yapma çabası görülmüştür. Bu Amerikanvarileşen siyaset yapma tarzının en tipik özellikleri; parti yerine lider ve ideoloji yerine imajın ön plana çıkarılmasıdır ( Kılıçaslan, 2011: 3).

"Bir partiye veya onun liderine duyulan "duygusal bağlılık" oy verme davranışı üzerinde etkili olmaktadır. Aynı şekilde dini ve siyasal inançlar da kişilerin oy verme davranışı üzerinde etkili olabilmektedir" (Özkan, 2004: 109). "Parti liderlerinin seçmen kitlesi ve tercihi üzerindeki etkisi de giderek güçlenmiş hatta siyasal partiler lider partisine dönüşmüştür. Bu, Sennet'e göre özel/kişiselin kamusal üzerine dayatılmasının siyasal alandaki bir sonucudur" (Yıldız, 2002: 98).

"Lider kendisini çalıştığı ortamın kanaatleri ile uyumlu halde tutmak zorundadır; aldığı kararları inandırıcı ve tatmin edici biçimde almak, savunmak ve kabul ettirmek zorundadır" (Karlöf’ten aktaran Altıntaş, 2001: 41). "Siyasal liderliğin en belirgin göstergesi kitlelerin düşünceden eyleme uzanan süreçlerini etkileyerek yönlendirebilmektir. Etki ve yönlendirme siyasetçi ile lider ayrımının da belirleyicisidir" (Yalın, 2012: 85).

Politik pazarlama bakış açısıyla parti lideri; partisinin ürünü olan programı ve ideolojisi ile birlikte kendisinin kişisel yapısının bütünleşmesinden oluşmuş karma 
2014 Ankara yerel seçimlerinde parti lideri faktörünün...

bir politik ürün yapısını temsil etmektedir. Bu manada parti lideri; partisinin vitrini ve tanıtımının en yoğun ilgi noktasını oluşturmaktadır. Seçmen, partinin söylemlerini, programını, olaylara karşı duruşunu ve tavırlarını en yoğun şekilde parti liderinin söylem, duruş ve tavırları üzerinden öğrenir ve kanaat oluşturur. Parti liderinin kamusal görevi partisinin yüzü olmak ve sesini duyurmaktır. Özellikle siyasi bir partinin ürünü lideri, adayları, üyeleri, üyeleri, personeli, sembolleri kurumu, parti politikaları gibi değişik unsurlardan oluşmaktadır (LeesMarshment'den aktaran Öcal vd., 2011: 404). Bunların içinde lider, parti programı ve parti ideolojisi en önemli olanlarıdır.

Son zamanlarda yapılan kamuoyu araştırmaları, seçim kampanyaları ve seçim sonuçları; kararsız seçmen sayısının arttığını ve toplumsal ve siyasal grup bağlarının zayıfladığını, hayatın rasyonelleşerek tek tipleştiğini göstermektedir. Böylece siyasal alanda partilerden çok liderlerin ön plana çıkmasıyla birlikte, siyasal pazarlama teknikleri ve imaj kavramı siyasi hayatın vazgeçilmez bir parçası haline gelmiştir. $\mathrm{Bu}$ amaçla hazırlanan kampanyalar, siyasi liderleri tanıtmak ve daha çok seçmenin desteğini kazanmak için, kitle iletişim araçlarını kullanarak parti liderlerini ticari bir ürün gibi pazarlamak amacıyla hazırlanmaya başlamış, böylece parti liderlerine yönelik imaj kavramını ön plana çıkartmıştır (Özel, 2009: 169).

"Artık siyasal kampanyalar parti ideolojilerinin ve programlarının tanıtımına ağırlık veren özelliklerinden uzaklaşmış ve lidere odaklanmıştır” (Özkan, 2007: 22). “Günümüz seçimlerinde ideolojiden çok psikoloji dolayısı ile umutlara ve geleceğe seslenen lider ön plandadır" (Balcı, 2005: 161).

Uztuğ, Liderin kişisel özelliklerini; karakteri, hitabeti, dürüstlüğü, eğitimi, güvenilirliği olarak ele almaktadır (1999: 152). Bu anlamda;

AKP lideri Recep Tayip Erdoğan'ın İstanbul Belediye Başkanlığı döneminden beri süregelen başarılı politikacı ve yönetici imajı ve onun seçim kampanyalarındaki ılımlı hitabeti, AKP'yi İslami değerleri savunan seçmenlerden, kırsal milliyetçilerden ve 1 lımlı kent seçmenlerinden oluşan geniş bir seçmen yelpazesi için tercih edilebilir kılmıştır (Çağatay, 2002: 42-48). 


\section{Oy Verme Davranışları}

5.1 Sosyolojik yaklaşım: “İlk olarak Colombia Üniversitesi (ekolü-okulu) tarafından yapılan çalışmalarda ortaya atılan bu yaklaşım” (Hülür ve Kalender, 2002: 2); bireyselciliği reddederek, seçmen bireyin oyunu içinde bulunduğu grubun etkisinde kalarak belirlediğini savunmaktadır. Tutum ve değer sistemlerinin sonucu bireysel davranışın olmadığı yaklaşımda, seçmenin oy verme kararında daha ziyade din, sosyo-ekonomik statü, yaşanılan coğrafya ve mensup olunan grup belirleyici olmaktadır. (Kalender, 2000: 52; Özkan, 2004: 111). Birey sosyal olarak politikleşir ve sosyal özellikler parti tercihini belirler, oy verme temel olara bir grup deneyimidir. Birlikte çalışan seçmenlerin aynı adaya oy vermeleri muhtemeldir. Oy vermede aile unsuru önemli etkendir. Seçimlere gösterilen ilgi düzeyi karar verme süreciyle orantılıdır (Damlapınar ve Balc1, 2014: 105; Özkan, 2004: 112). Türkiye'de sosyolojik oy verme davranışı konusunda oldukça saha çalışması yapılmıştır. Bunları kronolojik olarak; Abadan, 1965; Sencer, 1974; Özbudun, 1975; Erdoğan, 1992; Kalaycıoğlu, 1994; Narlı ve Dirlik, 1996, Köktaş, 1997; Hülür ve Kalender, 2002 ve 2003; Çarkoğlu ve Hinich, 2006; Akarca ve Tansel, 2007 ve Eser, 2012 şeklinde sıralamak mümkündür (Damlapınar ve Balc1, 2014: 106).

5.2 Psikolojik yaklaşım: Michigan Okulu olarak bilinen ekol; partiyle özdeşleşme olarak da ifade edilen bir yaklaşım savunmaktadır. Bu ekole göre; "seçmenin bir partiye duyduğu sevgi, sempati ve bağl1lı̆̆ ifade eder. Temel tezleri; seçmenin partizan tercihlerinin, bir psikolojik güçler sahasını kapsayan yönü ve gücüne bağlı olduğudur. Tutumların yönü ve yoğunluğunun ölçülmesi, çoğu seçmen davranışını hesap etmede kullanılabilmektedir" (Özkan, 2004: 112-113). Colombia ekolünün sosyolojik yaklaşım görüşlerini reddeden bu ekole göre; bireyi ve onun siyasal tutumunu öne çıkarmıştır. Çoğu seçmenin geçmişten gelen bir sevgi bağı ile bir partiye bağlılığ 1 o partiye oy vermesindeki asıl tutumunu oluşturmaktadır. $\mathrm{Bu}$ durum bireyin siyasal toplumsallaşma süreci ile ilgilidir. Siyasal parti gelişim süreci olarak değerlendirilen bu yaklaşım, dini bağlılık ve toplumsal aidiyetlere benzetilmiştir. Bu özellikler kısa zamanda değişikliğe uğramamaktadır (Damlapınar ve Balc1, 2014: 101). 
2014 Ankara yerel seçimlerinde parti lideri faktörünün...

5.3 Rasyonel tercih yaklaşımı: Bu yaklaşımda temel varsayım; "seçmenlerin kendi amaç, istek ve talepleri doğrultusunda davranarak çıkarlarını koruyucu en uygun partiye oy vermelerine dayanmaktadır" (Kalender, 2005: 50-51). Bu seçmen davranışında, psikolojik davranıştaki duygusal bağlılığın aksine, seçmen parti ilişkisinde seçmenin çıkarları partiye oy vermeyi sağlamaktadır, seçmeni tercihini çevresel faktörler etkilememektedir. Bizzat seçmen kararını oluştururken mukayese edebilmek için daha çok bilgi kaynağına başvurmaktadır (Damlapınar ve Balcı, 2014: 109; Kalender, 2005: 50-52).

Rasyonel tercih yaklaşımında seçmen, geleceği değil, geçmişi sağduyu ile değerlendirir ve oyunu buna göre belirler. İktidardaki partinin vaatleri ile icraatlarına bakar ve kendi menfaatleri ile karşılaştırır. Son yıllarda Türkiye'de seçmenin önemli bir kısmı rasyonel tercih yaklaşımını benimsemiş görünmektedir. Parti bağlılıkları olmayan bu seçmen tipi, kimin daha iyi yöneteceğine inanıyorsa oyunu ona vermektedir (Özkan, 2004: 116). Kitle iletişim araçlarındaki muazzam teknolojik gelişmelerin de etkisiyle değişen dünya şartlarında bireysel davranışların güçlendiği varsayımı bu seçmen davranış tipini artırmaktadır.

\subsubsection{Konuya oy verme ve ideolojiye oy verme yaklaşımları}

Yukarıda sunulan üç tip oy verme davranışının yanında literatürde konuya oy verme ve ideolojiye oy verme yaklaşımları da yer almaktadır. Bunlarda ilk yaklaşıma göre; “adayın veya partililerin ülke ve bölge sorunlarına karşı tutumları seçmen tercihini belirlemede önemli bir etken sayılmaktadır. Özellikle seçim kampanyalarında gündemdeki konular hakkında gösterilen tutumlar farklı siyasal birikime sahip seçmenler üzerinde etkili olabilmektedir" (Güllüpunar, 2010: 83). Bu yaklaşıma göre seçmen kampanya boyunca siyasal adaylar partiler ve liderler tarafından ülke gündemindeki konuların işlenmesi ve gösterdikleri tavır ve yaklaşımlar seçmenin oy verme kararında etkili olabilmektedir. İkinci yaklaşıma göre ise; oy verilen partiye karşı beslenen ideolojik sevgi ve sempati seçmenin oy verme kararında etkin olabilmektedir. 
2014 Ankara yerel seçimlerinde parti lideri faktörünün...

Aslında ideolojik oy verme yaklaşımı; siyasal iletişim araştırmacılarının “seçmen oy verirken ideolojiyi dikkate alır m?" sorusuna verilen cevapların sorgulandığı bir yaklaşımdır (Kalender, 2005: 61). Özellikle Türk seçmeninde ideolojik oy verme yaklaşımının etkili olduğu birçok çalışmada ortaya konmuştur. Sözgelimi; Çaha, Toprak ve Dalmış'ın (1996: 205-247) Kırıkkale il merkezi evreninde yaptıkları saha araştırmasında; parti üyelerine dönük üye oldukları partiyi tercih sebepleri sorusunun cevabı \% 18,2 ile ideolojik nedenlerin yer aldığ 1 verilen cevaplar oluşturmuştur. Doğan ve Göker (2010: 183) tarafından Elazığ'da yapılan bir araştırmada; seçmenin oy verirken parti liderini ve partinin ideolojisini de dikkate aldığı tespit edilmiştir. Daha doğrusu Türk seçmeninin ideolojik bir tutumu bulunmaktadır (Güllüpunar vd., 2013: 10 -11; Damlapınar ve Balc1, 2014: 116; Çarkoğlu ve Toprak, 2006: 37).

\section{Parti Liderinin Seçim Sonuçlarına Etkisi}

“Türkiye'de yerel seçimler; yerel yönetimlerin seçilmesi, tercih edilme süreci olarak değil, merkezi hükümetin seçmenler tarafından test edildiği bir süreç olarak algılanmaktadır” (Çitçi, 2005: 37). "Türkiye'de liderler siyasetin en önemli etkenidir. Siyaset süresince liderlerin belirleyiciliği yalnızca Türkiye için değil, diğer birçok ülke için de geçerlidir. Artık siyasetin temel aktörü partiler yerine liderlerdir ve bu gerçek, siyasal sistemden bağımsızdır" (Yıldız, 2002: 81).

Çaha, Toprak ve Dalmış’ın (1996: 205-247) Kırıkkale il merkezinde yaptıkları saha araştırmasında; parti üyelerine dönük üye oldukları partiyi tercih nedenleri sorusunun cevabı \% 21,3 ile ilk sırada lider olmuştur. Neticede Duverger'in (1984: 15) yaklaşımı ile "politika yapmanın bir savaş yapmak olduğunu düşündüğümüzde; bu savaşın en stratejik silahının kitle iletişim araçlarının olduğunu da bilmemiz gerekmektedir".

Damlapınar ve Balcı'nın yaptıkları bir tespitte $(2014,98)$; seçmenin oy verme kararında sosyal karakteristikler, grup dinamikleri, partiyle özdeşleşme, güncel konular, mevut siyasal parti imajı ve nihayet liderleri değerlendirme gibi süreçlerin birbirleriyle de etkileşim içinde oldukları vurgulanmaktadır. Akıncı ve Akın'ın 
2014 Ankara yerel seçimlerinde parti lideri faktörünün...

yaptıkları bir araştırmada (2013:348); siyasi lider figürünün, partisini doğrudan kendisinin yönettiği ve dolaylı olarak medya üzerinden yönlendirebileceği iletişimler ile partiye olan sadakat, parti programı ve politikalarının algılanmasını dolayısıyla da seçmen tercihine etkisini şekillendirdiği sonucuna varılmıştır.

\footnotetext{
Seçmenler siyasal tercihlerini belirlerken, içinde bulundukları gruplar, ideolojik görüşleri, ekonomik ve toplumsal koşullar, iktidar ve muhalefet partilerinin performansı, vaadleri ve adaylar gibi unsurlardan etkilenirler. Ancak seçmenin siyasi tercihlerini etkileyen en önemli unsur hiç kuşkusuz parti lideridir. Bu etki siyasal partinin varlığını ve sürekliliğini belirleyecek kadar güçlüdür (Yalın, 2012: 82-83).
}

"Başarılı örgütlerin yöneticileri üzerinde yapılan araştırmalar, bu yöneticilerin, başarısız örgütlerin yöneticilerine oranla daha çok liderlik özellikleri gösterdiklerini ortaya çıkarmıştır” (Peters ve Waterman'dan aktaran Başaran, 1992: 96).

Siyasal partiler siyasal pazarlama açısından değerlendirildiğinde; siyasal kurumsal temsiliyet olarak parti lideri siyasal ürünü oluşturan en önemli ve en göze çarpan tarafını oluşturmaktadır. Öyle ki; bazı durumlarda elde edilen “oy”un çok önemli bir kısmının bizzat lidere ait olduğu iddia edilmektedir. Örneğin 3 Kasım 2002 seçimlerinde AK Parti'nin almış olduğu yaklaşık \% 35'lik oyun çok büyük bir kısmının Recep Tayyip Erdoğan'a ait olduğu zaman zaman birçok siyasetçi tarafından dile getirilmiştir (Polat vd., 2004: 101-102).

30 Mart 2014 yerel seçimlerinin hemen ardından, İpsos-Sosyal Araştırmalar Enstitüsü'nün CNN-Türk için yaptığı araştırmada; Ak Parti'ye oy verenlerin lider ve icraatı tercih ettiği ortaya çıkmıştır. Yapılan araştırmada; ülkenin olağanüstü koşullarda girdiği gerilimli 30 Mart 2014 yerel seçimlerinde; seçmenin oy verme kararında nelerin etkili olduğu ve ülkedeki tüm siyasal kaotik olumsuzluklara rağmen AK Parti'nin seçimlerden başarılı çıkış nedenleri sorgulanmıştır. Araştırma sonunda; Ak Parti’ye oy verenlerin \% 84 'ü parti lideri faktöründen etkilendiğini belirtirken, bu oran CHP'de \% 55, MHP'de ise; 67 olarak çıkmıştır (https//www.Milliyet.om.trErdoğan çarpıcı bir zafer kazandı-/siyaset/detay). 
2014 Ankara yerel seçimlerinde parti lideri faktörünün...

\section{Araştırmanın amacı ve Süreci}

Yerel seçim kampanyalarında siyasal partilerin, parti liderlerinin ve adayların siyasal mesajlarını seçmene iletme sürecinde, siyasal halkla ilişkiler açısından kullanmış oldukları teknik ve iletişim araçlarının kullanımı bakımından hangi faktörlerin iletişim kurmak ve ikna etme açısından seçmen davranışı üzerinde etkili olduğunu ortaya koymak ve seçmenin siyasal oy verme davranışlarında etkili olan etmenlerin tespit edimesi amaciyla, 30 Mart 2014 yerel seçimlerinde Ankara Büyükşehir Belediye Başkanlığı seçimleri ile ilgili ampirik bir çalışma yapılmıştır. Yapılan çalışmada, 30 Mart yerel seçimlerinin hemen ardından 31 Mart 2014 tarihinden itibaren başlanarak 15 gün içinde Ankara şehir merkezi genelinde 600 denekle yüz yüze tesadüfi örnekleme dayalı bir saha araştırması gerçekleştirilmiştir.

Araştırmada aşağıdaki sorulara cevap aranmıştır.

- Seçmenin oy verdiği partiye, parti liderine ve adaya bağlılıkları var mıdır? Varsa bu bağlılık düzeyleri nasıl ölçümlenerek tespit edilebilir?

- Seçmenin seçim kampanyası süresince oy verme karar zamanları farklılaşıyor mu? Farlılaşıyor ise; seçmenin kime oy vereceği kararı hangi zaman aralıklarında belirginleşiyor?

- Seçmen kendisini; siyasal olarak bilinen ideolojik yaklaşımlardan hangisi ile tanımliyor?

- Seçmenin seçim kampanyasına ilgi düzeyi nasıldır?

- Seçmenin oy verme kararında en önemli etmen ne olabilir?

- Katılan seçmen hangi partiye oy vermiştir?

\subsection{Araştırma Metodolojisi}

Saha çalışması anketinde; 2014 yerel seçimlerinde, Ankara seçmeninin büyükşsehir belediye başkanlığı seçimlerinde oy verirken hangi etmenlerin oy verme kararında ne derece etkili olduğunu sınamanın yanında deneklere; siyasal içerikli sorular da sorulmuştur. Bu sorularla, seçmenin oy verdiği partiye, parti liderine ve 
adaya bağlılık düzeyleri ile seçim kampanyası sürecinde oy verme karar zamanı, siyasal olarak kendilerini nasıl tanımladıkları, seçim kampanyasına ilgi düzeyleri, oy vermelerindeki en önemli etmenin ne olduğu, hangi partiye oy verdikleri ölçülmeye çalışılmıştır.

Ankette; deneklerin meslek, eğitim, gelir, medeni durum, cinsiyet ve yaş gibi sosyo-demografik özelliklerini elde etme amacıyla sorular da düzenlenmiştir.

Araştırmada elde edilen değişken verilerinin karşılaştırılmasında kategorik (nominal) düzeydeki değişkenlerin birbiriyle ilişkisinde ve aynı değerler bakımından cinsiyetlere göre değerlendirme yapabilmek maksadıyla "Ki kare testi” yapılmıştır.

\subsection{Bulgular ve Yorum}

Araştırmaya katılan 600 deneğin sosyo-demografik özelliklerinin belirlenmesi amacıyla deneklere yaşları, cinsiyetleri, meslekleri, eğitim durumları ve aylık gelirleri ile ilgili sorular sorulmuştur. Ayrıca seçmenlerin 2014 yerel seçimlerinde hangi partiye oy verdikleri ve oy verdikleri partiye ve parti liderine bağl1lık düzeyleri ile ilgili sorular sorulmuştur.

\subsection{Katılımcıların Sosyo-Demografik Özellikleri}

7.3.1 Katılımcıların Cinsiyete Göre Dağılımı:

\begin{tabular}{lll}
\hline & Kişi Sayısı & Yüzde \\
\hline Kadın & 247 & 41,1 \\
Erkek & 352 & 58,7 \\
Cevapsız & 1 &, 2 \\
\hline TOPLAM & & \\
\hline
\end{tabular}

Cinsiyet açısından araştırmaya katılanların \% 58,7'sinin erkek, \% 41,1'nin de kadın olduğu görülmektedir. Erkeklerin kadınlardan fazla olmasının nedeni, anket araştırmasında deneklerin kamuya açık mekânlarda tespit edilmesi ve erkeklerin ankete katılma isteğinin kadınlardan daha fazla olmasından kaynaklanmaktadır. 


\subsubsection{Katılımcıların Yaş durumu}

\begin{tabular}{lll}
\hline & Kişi Sayısı & Yüzde \\
\hline $18-25$ yaş arsı & 205 & 34,3 \\
$26-33$ yaş arası & 111 & 18,5 \\
34-41 yaş arası & 67 & 11,2 \\
$42-49$ yaş arası & 85 & 14,2 \\
$50-57$ yaş arası & 73 & 12,2 \\
$58-65$ yaş arası & 38 & 6,3 \\
65 yaş üstü & 20 & 3,3 \\
\hline Toplam & 599 & 100,0 \\
\hline Cevapsız & 1 & \\
\hline TOPLAM & 600 & \\
\hline
\end{tabular}

Yaş dağılımı bakımından katılımcıların yarıdan fazlasının (\% 52,7) 33 yaşın altında genç sayılabilecek bir özelliğe sahip olduğu ve buna karşılık 65 yaş üstünün katılanlar arasında \% 3,3'e denk geldiği görülmektedir. Orta yaş sayılabilecek 34-49 yaş arasında katılanların oranı \% 25,4 olarak gerçekleşmiştir.

\subsubsection{Katılımcıların Eğitim Durumu}

\begin{tabular}{lcc}
\hline & Kişi Sayısı & Yüzde \\
\hline Okur-yazar değil & 8 & 1,3 \\
Okur-yazar & 6 & 1,0 \\
Illkokul mezunu & 43 & 7,2 \\
Ortaokul mezunu & 41 & 6,8 \\
Lise mezunu & 141 & 23,4 \\
Üniversite mezunu & 324 & 54,1 \\
Lisansüstü+ & 36 & 6,0 \\
Cevapsız & 1 & 0,2 \\
\hline TOPLAM & $\mathbf{6 0 0}$ & $\mathbf{1 0 0 . 0}$ \\
\hline
\end{tabular}

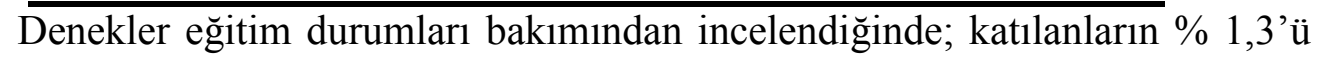
okur- yazar olmadıklarını ifade etmişlerdir. Diğer katılanlardan \% 1'nin okuryazar, \% 7,2'sinin ilkokul, \% 6,8'nin 10,4'nün ortaokul, \% 23,5'nin lise, \% 54,1'nin üniversite ve \% 6'nın yüksek lisans ve doktora düzeyinde eğitime sahip olduğu görülmüştür. Araştırmaya katılanlar üniversite mezunu ve üniversite mezunu olmayan şeklinde bir ayırıma tabi tutulduğunda; üniversite mezunlarının oranının \% 60'dan fazla olduğu görülmektedir. 


\subsubsection{Katılımcıların Ekonomik Durumu}

\begin{tabular}{lcc}
\hline & Kişi Sayısı & Yüzde \\
\hline 1.000 TL.'ye kadar & 208 & 34,7 \\
1.001-2.000 TL. arası & 183 & 30,6 \\
2.001-3.000 TL arası & 110 & 18,4 \\
3.001-4.000 TL. arası & 43 & 7,2 \\
4.001-5.000 TL. arası & 32 & 5,3 \\
5.000 TL. ve üstü & 23 & 3,8 \\
Toplam & $\mathbf{5 9 9}$ & $\mathbf{1 0 0 . 0}$ \\
\hline Cevapsız & 1 & \\
\hline TOPLAM & $\mathbf{6 0 0}$ & $\mathbf{1 0 0 . 0}$ \\
\hline
\end{tabular}

Katılımcıların ortalama aylık toplam gelirlerine ilişkin betimleyici istatistik sonuçlarına bakıldığında, 65,3'nün aylık ortalama gelirinin 2.000 TL.'nin altında olduğu görülmektedir. Katılanların çoğunluğunun ekonomik durumlarının 2.000 Tl.'nin altında çıkmasında katılanlar arasında genç ve öğrenci sayısının fazla olması etkili olmuştur. Katılanların 2.001 ile 4.000 TL. arasında geliri olanların oranı \% 25,6 olarak gerçekleşmiştir. 4.001 ile 5.000 TL. arası geliri olanlar \% 5,3’tür. 5.000 TL. üstü gelire sahip olanlar ise sadece $\% 3,8^{\prime}$ dir.

\subsubsection{Katılımcıların Mesleki Durumu}

\begin{tabular}{lcc}
\hline & Kişi Sayısı & $\begin{array}{c}\text { Yüzde } \\
\text { (\%) }\end{array}$ \\
\hline İşçi & 109 & 18,2 \\
Memur & 97 & 16,3 \\
Esnaf & 35 & 5,8 \\
Serbest meslek & 57 & 9,5 \\
Emekli & 67 & 11,2 \\
Sanayici-Tüccar & 11 & 1,8 \\
Ev hanımı & 41 & 6,8 \\
Öğrenci & 165 & 27,5 \\
İşsiz & 10 & 1,7 \\
Diğer & 7 & 1,2 \\
\hline Toplam & 599 & 99,8 \\
\hline Cevapsız & 1 &, 2 \\
\hline TOPLAM & $\mathbf{6 0 0}$ & $\mathbf{1 0 0}$ \\
\hline
\end{tabular}

Meslek açısından katılımcıların yüzde 18,2'si işçi, yüzde 16,3'ü memur, yüzde

5,8'i esnaf, yüzde 9,5'i serbest meslek, yüzde 11,2'si emekli, yüzde 1,8'i sanayicitüccar, yüzde 6,8'i ev hanımı ve yüzde 27,5'i öğrencidir. Meslek sorusuna "diğer" ifadesinin yer aldığı katılanın mesleğini belirlemesi istenmiştir. Katılanların \% 1,7'si ucu açık meslek sorusuna “işsiz" olduğunu belirtmiş ve 1,2'si de diğer ifadesinde bulunmuştur. 


\subsubsection{Katılımcıların Medeni Durumu}

\begin{tabular}{lcl}
\hline & Kişi Sayısı & Yüzde \\
\hline Evli & 314 & 52,4 \\
Bekâr & 285 & 47,6 \\
\hline Toplam & 599 & 100.0 \\
\hline Cevapsız & 1 & \\
\hline TOPLAM & $\mathbf{6 0 0}$ & \\
\hline
\end{tabular}

Medeni duruma göre katılımcıların yüzde 52,4 evli, yüzde 47,6'sı ise bekârdır. Araştırmada medeni duruma göre elde edilen değerlerde yarı yarıya yakın bir durum söz konusudur. Bekârların evli olanlara yakın olmasında araştırma evreninde genç nüfusun fazla olmasından kaynaklanmaktadır.

\subsection{Yerel Seçimlerde Katılanların Siyasal Davranışlarının Değerlendirilmesi 7.4.1 Katılanların Oy Verdiği Parti}

\begin{tabular}{lcc}
\hline Oy Verilen Parti & Kişi Sayısı & Yüzde \\
\hline Ak Parti & 252 & 42,1 \\
\hline CHP & 248 & 41,3 \\
\hline MHP & 77 & 12,9 \\
\hline İşçi Partisi & 6 & 1,0 \\
\hline HDP & 4 & 0,8 \\
\hline BBP & 4 & 0,8 \\
\hline Yurt Partisi & 3 & 0,06 \\
\hline Saadet Partisi & 2 & 0,3 \\
\hline Türkiye Komünist Partisi & 1 & 0,2 \\
\hline Toplam & $\mathbf{5 9 7}$ & $\mathbf{1 0 0}$ \\
\hline Cevapsız & 3 & $\mathbf{1 0 0}$ \\
\hline TOPLAM & $\mathbf{6 0 0}$ & \\
\hline
\end{tabular}

Deneklerin 2014 Ankara Büyükşehir Belediye Başkanlığ yerel seçimlerinde hangi partiye oy verdikleri ele alındığında; \% 42,1'i Ak Parti'ye, \% 41,3'ü CHP'ye, \% 12,9'u MHP'ye, \% 1'i İşçi Partisi'ne ve \% 2,7'sini de diğer partilere oy verdikleri görülmektedir. Hangi partiye oy verdiğini belirtmek istemeyenler ise önemsiz kadar azdır ve sadece 3 kişi oy verdiği partiyi belirtmemiştir.

$\mathrm{Bu}$ saha çalışması Ankara Büyükşehir Belediye Başkanlığı yerel seçimleri kesin sonuçları ile kıyaslandığında; seçim sonuçlarına göre, Melih Gökçek'in aday olduğu AK Parti \% 44,9, Mansur Yavaş'ın aday olduğu CHP \% 43,8, Mevlüt Karakaya'nın aday olduğu MHP \% 7,8, BBP \% 1,3 oy almış ve diğer partiler ciddi 
bir varlık gösterememişlerdir. Dolayısıyla seçimlerde alınan kesin sonuçlar ile yapılan saha çalışmasında elde edilen sonuçlar birbiri ile örtüşmektedir. Çünkü kesin seçim sonuçları; seçimlerin Ak Parti'li Melih Gökçek ile CHP'li Mansur Yavaş arasında geçtiğini göstermektedir. İki rakip aday ve partinin aldıkları sonuçlar arasındaki fark sadece \% 1,1 olarak gerçekleşmiştir. Yapılan saha çalışmasında elde edilen sonuçlarda da seçimlerin AK Parti adayı Melih Gökçek ile CHP adayı Mansur Yavaş arasında geçtiği teyit edilmekte ve iki aday arasındaki fark sadece 0,8 olarak tespit edilmiştir. Hal böyle olmakla birlikte, seçim kesin sonuçları itibariyle \% 7,8 oy alan MHP, saha araştırmasında \% 12,9 çıkmış ve aradaki fark \% 5,1 olarak gerçekleşmiştir

\subsubsection{Katılanların Parti, Lider ve Adaya Bağlılık Durumları Değerlendirmesi}

\begin{tabular}{|l|c|c|c|}
\hline \multicolumn{2}{|c|}{ Betimleyici İstatistikler } \\
\hline & $\mathrm{N}$ & $\overline{\mathrm{X}}$ & SD \\
\hline Parti Bağlılı̆̆ı & 600 & 7,07 & 2,80 \\
\hline Lidere Bağlılık & 600 & 6,78 & 3,13 \\
\hline Adaya Bağlılık & 600 & 6,76 & 2,93 \\
\hline
\end{tabular}

2014 Ankara Büyükşehir Belediye Başkanlığı yerel seçimleri araştırmasında katılanların parti, aday ve lidere bağlılık düzeyleri 1'den 10'a kadar puanlama yöntemi ile ölçülmeye çalışılmıştır. Araştırma sonucunda katılanlarda 10 üzerinden 7,07 ortalama ile parti bağlılığı, 6,78 ortalama ile lider bağlılı̆̆ ve 6,76 ortalama ile aday bağl1lığg olduğu görülmüştür.

$\mathrm{Bu}$ ortalamalar ve elde edilen sonuçlar Türk seçmenin siyasal tutumunda parti, lider ve aday bağlılığı önemli bir yer tutmaktadır.

\subsubsection{Katılanların Partiye Bağlılık Düzeyleri}

\begin{tabular}{|l|c|c|}
\hline Partiye Bağlılık Düzeyleri & Kişi Sayısı & Yüzde (\%) \\
\hline Çok zayıf & 74 & 12,3 \\
\hline Zayıf & 43 & 7,2 \\
\hline Orta Düzey & 113 & 18,8 \\
\hline Güçlü & 103 & 17,2 \\
\hline Çok Güçlü & 267 & 44,5 \\
\hline Toplam & 600 & 100 \\
\hline
\end{tabular}


2014 Ankara yerel seçimlerinde parti lideri faktörünün...

Araştırmaya katılanlara öncelikle 1-10 arasındaki skala ile oy verdikleri partilere bağl1lık düzeyleri sorulmuştur. Buna göre yukarıdaki veriler göz önünde tutulduğunda, seçmenlerin oy verdikleri partiye bağl1lı düzeyi ortalaması 7,07 olarak gözlenmektedir. $\mathrm{Bu}$ çerçevede seçmenlerin büyük çoğunluğun güçlü sayılabilecek bir düzeyde partilerine bağlılık geliştirdikleri ortaya çıkmaktadır. Veriler ayrıntılı incelendiğinde ise araştırmaya katılanların \% 12,3'nün partilerine bağlarının çok zayıf olduğu, \% 7,2'sinin zayıf olduğu, 18,8'nin orta düzey olduğu görülmektedir. Partilerine güçlü ve çok güçlü bağlarla bağlanan seçmenlerin oranı yüzde 61,7 olup, örneklemin yarısından çoğunun partiye bağlı olduğu sonucu ortaya çıkmaktadir.

\subsubsection{Katılanların Parti Liderine Bağıııık Düzeyleri}

\begin{tabular}{|l|c|c|}
\hline $\begin{array}{l}\text { Parti Liderine Bağlılık } \\
\text { Düzeyleri }\end{array}$ & Kişi Sayısı & Yüzde (\%) \\
\hline Çok zayıf & 86 & 14,3 \\
\hline Zayıf & 60 & 10,0 \\
\hline Orta Düzey & 103 & 17,2 \\
\hline Güçlü & 112 & 18,7 \\
\hline Çok Güçlü & 239 & 39,8 \\
\hline Toplam & 600 & 100 \\
\hline
\end{tabular}

Araştırmaya katılanlara öncelikle 1-10 arasındaki skala ile oy verdikleri parti liderine bağlılık düzeyleri sorulmuştur. Buna göre seçmenlerin oy verdileri parti liderine bağlılık düzeyi ortalaması 6,78 olarak gözlenmektedir. Deneklerin oy verdikleri parti liderine bağlılık düzeylerine bakıldığında; \% 24,3'nün parti liderine bağlı olmadıkları değerlendirmesi yapılabilir. Bununla birlikte katılanların \% 39,8'nin parti liderine bağlılıklarının çok güçlü olduğu ortaya çıkmıştır. Deneklerin \% 18,7'nin oy verdikleri parti liderine bağl1lıklarının güçlü olduğu, \% 17,2'nin de orta düzeyde bağl11ıklarının olduğu anlaşılmaktadır.

Burada şu yorumu yapmak mümkündür; toplumda seçmenin siyasal katılımlarını ve siyasal kararlarını belirlemede lidere bağlılık çok önemli bir etkendir. Ayrıca araştırmada elde edilen oy verdiğim parti liderine bağlılık derecem çok güçlü diyenlerle güçlü diyenlerin toplamı \% 58,5'dir. Buna orta düzeyde bağl1lık derecesi 
2014 Ankara yerel seçimlerinde parti lideri faktörünün...

yüzdesi de $(17,2)$ ilave edildiğinde araştırmada oy verilen parti liderine bağlılık düzeyinin $\% 75,7$ oranında var olduğu sonucuna varılmaktadır.

\subsubsection{Katılanların Adaya Bağlılık Düzeyleri}

\begin{tabular}{|l|c|c|}
\hline Adaya Bağlılık Düzeyleri & Kişi Sayısı & Yüzde (\%) \\
\hline Çok zayıf & 69 & 11,5 \\
\hline Zayıf & 63 & 10,5 \\
\hline Orta Düzey & 125 & 20,8 \\
\hline Güçlü & 124 & 20,7 \\
\hline Çok Güçlü & 219 & 36,5 \\
\hline Toplam & 600 & 100 \\
\hline
\end{tabular}

Araştırmaya katılanlara öncelikle 1-10 arasındaki skala ile oy verdikleri adaya bağl1lık düzeyleri sorulmuştur. Buna göre seçmenlerin oy verdileri adaya bağlılık düzeyi ortalaması 6,76 olarak gözlenmektedir. Araştırmaya katılanlar arasında oy verdikleri partinin adayına bağlılık düzeyi çok zayıf olanlar ile zayıf olanlarının \% toplamı \% 22'dir. Adaya bağl1lık düzeyi çok güçlü olan denek sayısı \% 36,5'dir.

Deneklerin oy verdikleri adaya bağlılık düzeyinin güçlü olduğu söylenebilir, ancak genelde oy verilen partiye ve lidere bağlılık düzeylerine bakıldığında, toplumda oy vermeye etkisi bakımından partiye bağl1lık düzeyinin ilk sırada olduğu, parti liderine bağlılık düzeyinin ikinci ve adaya bağl1lık düzeyinin üçüncü sırada olduğu sonucuna varılmaktadır. Bu durum Türkiye'de aday odaklı olması gereken yerel seçimlerin genellikle genel seçim havasında geçtiği tezine uygun düşmektedir.

\subsubsection{Oy Vermeyi Etkileyen Değişkenler ve Katılımcıların Demografik}

\section{Özellikleri}

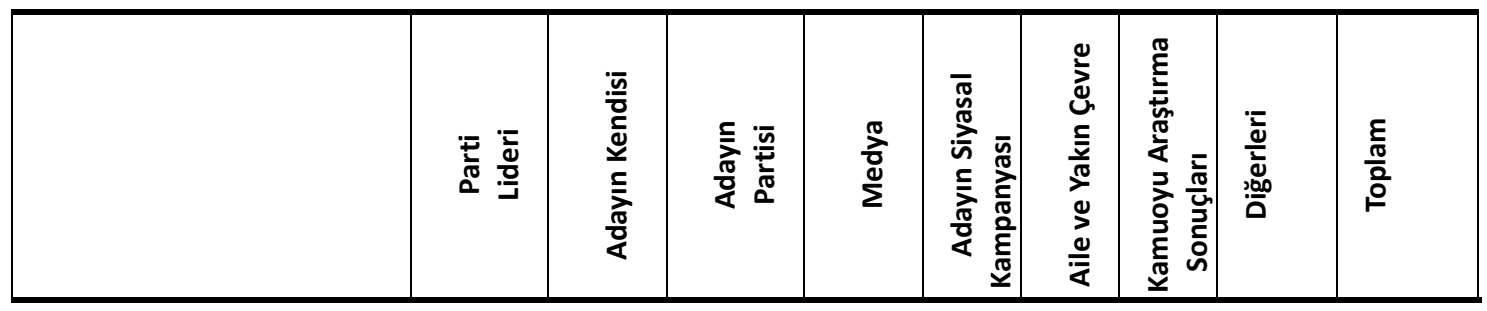

CINSIYET (\%) $x^{2}=(3,338 s d=4 p=, 503>0,01)$

\begin{tabular}{|l|l|l|l|l|l|l|l|l|l|}
\hline Kadın & 30,4 & 26,3 & 22,7 & 2,8 & 2,8 & 4,0 & 2,8 & 8,2 & 100,0 \\
\hline Erkek & 34,4 & 27,0 & 20,2 & 2,8 & 3,1 & 2,0 & 2,0 & 8,5 & 100,0 \\
\hline
\end{tabular}

YAŞ (\%) $\left(X^{2}=33,366 s d=24 p=, 097>0,01\right)$

\begin{tabular}{|l|l|l|l|l|l|l|l|l|l|}
\hline $18-25$ yaş arası & 28,3 & 33,2 & 18,0 & 2,9 & 4,4 & 2,0 & 3,4 & 7,8 & 100,0 \\
\hline
\end{tabular}


2014 Ankara yerel seçimlerinde parti lideri faktörünün...

\begin{tabular}{|c|c|c|c|c|c|c|c|c|c|}
\hline $26-33$ yaş arası & 30,6 & 20,7 & 19,8 & 4,5 & 5,4 & 4,5 & 0,9 & 13,6 & 100,0 \\
\hline 34-41 yaş arası & 37,3 & 26,9 & 17,9 & 4,5 & 0 & 3,0 & 1,5 & 8,9 & 100,0 \\
\hline $42-49$ yaş arası & 36,5 & 25,9 & 18,8 & 2,4 & 1,2 & 2,4 & 3,5 & 9,3 & 100,0 \\
\hline $50-57$ yaş arası & 39,7 & 19,2 & 27,4 & 0 & 1,4 & 4,1 & 2,7 & 5,0 & 100,0 \\
\hline 58-65yaş arası & 28,9 & 23,7 & 39,5 & 2,6 & 0 & 2,6 & 0 & 2,7 & 100,0 \\
\hline 65 yaş üstü & 40,0 & 30,0 & 25,0 & 0 & 5,0 & 0 & 0 & 0 & 100,0 \\
\hline
\end{tabular}

EĞітіM (\%) $\left(X^{2}=47,928\right.$ sd=24 p=,003<0,01)

\begin{tabular}{|l|l|l|l|l|l|l|l|l|l|}
\hline Okur-yazar değil & 37,5 & 0 & 50,0 & 0 & 0 & 0 & 0 & 12,5 & 100,0 \\
\hline Okur-yazar & 33,3 & 33,3 & 0 & 0 & 0 & 0 & 0 & 33,4 & 100,0 \\
\hline ilkokul & 34,9 & 23,3 & 32,6 & 2,3 & 0 & 0 & 0 & 6,9 & 100,0 \\
\hline Ortaokul & 43,9 & 22,0 & 7,3 & 7,3 & 2,4 & 0 & 4,9 & 12,2 & 100,0 \\
\hline Lise & 39,7 & 17,7 & 21,3 & 2,8 & 2,1 & 7,1 & 2,1 & 7,2 & 100,0 \\
\hline Üniversite & 28,7 & 30,6 & 21,6 & 2,5 & 4,0 & 2,2 & 2,8 & 7,6 & 100,0 \\
\hline Lisansüstü(+) & 25,0 & 41,7 & 16,7 & 2,8 & 2,8 & 0 & 0 & 11 & 100,0 \\
\hline
\end{tabular}

AYLIK GELIR (\%) $\left(X^{2}=22,463 \mathrm{sd}=20 \mathrm{p}=, 316>0,01\right)$

\begin{tabular}{|l|l|l|l|l|l|l|l|l|l|}
\hline 1.000 TL'ye kadar & 28,4 & 31,7 & 20,7 & 4,3 & 3,4 & 2,4 & 2,4 & 6,7 & 100,0 \\
\hline $1.001-2.000$ TL arası & 35,0 & 21,3 & 24,0 & 2,2 & 3,3 & 4,4 & 2,7 & 7,1 & 100,0 \\
\hline $2001-3000$ TL arası & 30,9 & 24,5 & 21,8 & 2,7 & 2,7 & 0,9 & 2,7 & 13,8 & 100,0 \\
\hline $3001-4000$ TL arası & 34,9 & 30,2 & 16,3 & 2,3 & 2,3 & 7,0 & 0 & 7 & 100,0 \\
\hline $4001-5000$ TL arası & 40,6 & 34,4 & 12,5 & 0 & 0 & 0 & 3,1 & 9,4 & 100,0 \\
\hline 5000 TL ve üstü & 47,8 & 17,4 & 21,7 & 0 & 4,3 & 0 & 0 & 8,8 & 100,0 \\
\hline
\end{tabular}

$\operatorname{MESLEK}(\%) \quad\left(X^{2} 2=59,846 \mathrm{sd}=36 \mathrm{p}=, 008<0,01\right)$

\begin{tabular}{|c|c|c|c|c|c|c|}
\hline İşçi & 31,2 & 26,6 & 15,6 & 22,9 & 3,7 & 100,0 \\
\hline Memur & 28,9 & 29,9 & 22,7 & 17,5 & 1,0 & 100,0 \\
\hline Esnaf & 34,3 & 17,1 & 28,6 & 17,1 & 2,9 & 100,0 \\
\hline Serbest meslek & 38,6 & 21,1 & 22,8 & 15,8 & 1,8 & 100,0 \\
\hline Emekli & 35,8 & 26,9 & 29,9 & 4,5 & 3,0 & 100,0 \\
\hline Sanayici-Tüccar & 72,7 & 9,1 & 0 & 18,2 & , 0 & 100,0 \\
\hline Ev hanımı & 48,8 & 4,9 & 31,7 & 7,3 & 7,3 & 100,0 \\
\hline Öğrenci & 26,7 & 33,3 & 18,2 & 18,8 & 3,0 & 100,0 \\
\hline İşsiz & 30,0 & 30,0 & 20,0 & 20,0 & & 100,0 \\
\hline Diğer & 14,3 & 71,4 & 0 & 14,3 & & 100,0 \\
\hline
\end{tabular}


2014 Ankara yerel seçimlerinde parti lideri faktörünün...

\subsubsection{Oy Vermeyi Etkileyen Değişken ve Cinsiyet İlişkisi}

Cinsiyete göre oy vermeyi etkileyen değiş̧kenler incelendiğinde, erkeklerin yüzde 34,4'ü ve kadınların yüzde 30,4'ü yerel seçimlerdeki siyasal tercihlerde parti liderinden etkilenmektedirler. $\mathrm{Bu}$ durum, erkeklerin kadınlara göre yerel seçimlerde oy verirken parti liderinden daha çok etkilendiklerini göstermektedir. Adayın kendisi ve partisi faktörünün kadınların ve erkeklerin oy vermelerinde önemsenecek düzeyde bir farklılığın olmadığı söylenebilir. Kadınların oy vermeyi etkileyen değiş̧kenlerden "aile ve yakın" çevreden erkeklere göre iki katı daha fazla etkilendikleri gözlenmiş̧ir. Öte yandan medya hem kadınları hem de erkekleri aynı oranda etkilerken, kamuoyu araştırma sonuçlarının kadınları erkeklere göre daha fazla etkilediği görülmektedir.

\subsubsection{Oy Vermeyi Etkileyen Değişken ve Yaş ilişkisi}

Yaş değişkeni ile oy vermeyi etkileyen değişkenler arasındaki ilişkiye bakıldığında; anlamlı bir ilişkinin olmadığı görülmektedir $\left(X^{2}=\mathbf{3 3 , 3 6 6}\right.$ sd=24 p=,097>0,01). 18-25 yaş aralığındaki katılımcıların yüzde 28,3'ü, 26-33 yaş arası; katılımcıların yüzde 30,6'sı, 34-41 yaş arası; katılımcıların yüzde 37,3'ü, $42-49$ yaş arasi; katılımcıların yüzde 36,5'i, 50-57 yaş arası; katılımcıların yüzde 39,7'si, 58-65 yaş arası; katılımcıların yüzde $28,9^{\prime}$ 'u ve 65 yaş üstü; katılımcıların yüzde 40 'ı oy verme kararlarında parti liderinin etkili olduğunu beyan etmişlerdir.

Katılanların yaşlarına göre oy verme tercihleri değerlendirildiğinde; 18-25 yaş arasındakilerin yüzde 33,2'si, 26-33 yaş arasındakilerin yüzde 20,7'si, 34-41 yaş arasındakilerin yüzde $26,9^{\prime} \mathrm{u}, 42-49$ yaş arasındakilerin yüzde $25,9,50-57$ yaş arasındakilerin yüzde 19,2'si, 58-65 yaş arasındakilerin yüzde 23,7'si ve 65 yaş ve üzerindekilerin yüzde $30,0^{\prime} \mathrm{u}$ adayın kendisini etkili bulmaktadır.

Oy verme davranışının şekillenmesi açısından adayın kendisini etkili görme, özellikle 18-25 yaş aralığındaki seçmenler arasında yoğunluk kazanmaktadır. Oy vermede adayın partisini etkili bulmada ise; 50 ile 65 yaş arası katılımcıların üstünlüğü bulunmaktadır. Bu yaş kategorisindeki katılımcılardan 50-57 yaş arasında bulunanların yüzde 27,4'ü, 58-65 yaş aralığında bulunanların yüzde 39,5'i ile 65 yaş 
üstü olanların yüzde 25'i bir yerel seçimde oy verme davranışını şekillendiren en önemli faktör olarak adayın bağlı olduğu partiyi etkili görmektedir.

$\mathrm{Bu}$ sonuçlara göre adayın partisini yerel seçimlerde etkili bulma açısından yüzde ile en düşük orana sahip grup, 18-25 yaş aralığındaki genç katılımcılardan oluşmaktadır. Oy vermede, medyanın etkisi yüzde 2,4'lük oranla en düşük 42-49 yaş arasında bulunurken, yüzde 4,5 ile 26-41 yaş arsında en yüksek olarak gerçekleşmiştir.

Diğer taraftan adayın siyasal kampanyası, aile ve yakın çevre ve kamuoyu araştırma sonuçları gibi oy vermeyi etkileyen faktörlerin katılanların 1,2 ile 5,4 arasındakiler arasında etkili olduğu görülmektedir.

\subsubsection{Oy Vermeyi Etkileyen Değişken ve Eğitim iliş̧isi}

Katılanların eğitim durumlarına bakıldığında, okur-yazar olmayanlarda, okuryazarlarda, ilkokul, ortaokul ve lise tahsillilerde oy verme kararında parti liderinin etkili olduğu oran yüzde 40'lara kadar çıkarken, üniversitelilerde yüzde 28,7, lisansüstü ve daha üstü eğitimlilerde yüzde 25'lere düşmektedir. Adayın kendisinin oy vermeyi etkilemesi bakımından değerlendirildiğinde; katılanlardan lise mezunlarının yüzde 17,7'sinde aday faktörü önemli olurken, bu oran üniversite mezunlarında yüzde 30,6 ve lisansüstü eğitimlilerde yüzde 41,7 olabilmektedir. Oy vermeyi etkileyen adayın partisi değişkeni açısından değerlendirmede; ortaokul mezunlarının parti lideri ve adayın kendisine yönelmeleri neticesinde adayın partisine oy verme oranı yüzde 7,3 olarak gerçekleşirken, lise ve üniversite mezunları arasında yüzde 20'ler civarında bir istikrar göstermektedir.

Elde edilen bu sonuçlara göre; oy vermeyi etkileyen değişkenler ile eğitim grupları arasında anlamlı bir farklılık vardır $\left(X^{\mathbf{2} 2=47,928 ~} \mathbf{s d = 2 4} \mathbf{p}=, \mathbf{0 0 3}<\mathbf{0 , 0 1}\right)$. Yerel seçimlerde seçmenlerin eğitim durumu oy verme alışkanlıklarında etkili olmaktadır ve bireyin eğitim durumu yükseldikçe adayın kendisine oy verme eğilimi artmaktadır. Medya yayınlarını etkili bulmada yüzde 7,3 ile ortaokul mezunları ilk sırada yer alırken, diğer eğitim düzeylerinden lise ve üstü olanlarda yüzde 2,5 civarında etkili olduğu görülmektedir. 


\subsubsection{Oy Vermeyi Etkileyen Değişken ve Ekonomik Durum ilişkisi}

Katılanlar ekonomik durumlarına göre değerlendirildiklerinde; aylık geliri 1.000 TL.'nin altında olanlardan yüzde 31,7'si adayı etkili bulurken, yüzde 28,4'ü parti liderini, yüzde 20,7'si de adayın partisini etkili bulmaktadır. 1.001-2.000 TL arası geliri olanlardan yüzde 35'i parti liderini, yüzde 24'ü partiyi ve yüzde 21,3’ü adayın kendisini etkili bulmaktayken, 2.001-3.000 TL. arası geliri olanlardan yüzde 30,9'u parti liderini, yüzde 24,5 'i adayın kendisini etkili bulmaktadır. Öte yandan parti liderinin etkisi 4.000 TL.'ye kadar olanlarda 34,9, 5.000 TL'ye kadar olanlarda yüzde 40,6 ve 5.000TL. üstü geliri olanlarda 47,8 çıkmaktadır.

\subsubsection{Oy vermeyi Etkileyen Değişken ve Meslek iliş̧kisi}

Katılanlar oy vermeyi değişkenler açısından meslek gruplarına göre değerlendirildiğinde, ilk olarak önemli bir durum olan sanayici ve tüccar meslek grubunda oy vermede en önemli etmen olarak parti lideri olgusunun ön plana çıkmaktadır. Bu grupta oy vermede rol oynayan en önemli etmen yüzde 72,7 ile parti lideri olmaktadır. Meslekler arasından oy vermede etkili olan parti lideri faktörünün ön plana çıktığı bir diğer meslek grubu yüzde 48,8 ile ev hanımlarıdır. Diğer meslek gruplarında oy vermede etkili olan parti lideri faktörü 38,6 ile serbest meslek, 35,8 ile emekli, 34,3 ile esnaf, 31,2 ile işçi, 28,9 ile memur ve 26,7 ile öğrenciler olarak gerçekleşmiştir. Meslek grupları içinden oy verme kararlarında etkili olan değişken olarak parti lideri faktörü tüm faktörler içinde ön plana çıkmaktadır. Meslek gruplarında oy verme en önemli değişken parti lideri faktörüdür. Meslek grupları açısından oy vermede diğer önemli değişkenlerde aday faktörü 33,3 ile öğrencilerde ve 29,9 ile memurlarda ön plana çıkarken, parti faktörü işçilerde yüzde 15,6 ile en düşük değeri ifade etmektedir. Yine meslek grupları arasında oy vermede önemli bir unsur olarak medya ön plana çıkmaktadır. İşçi grubunda yüzde 22,9 ile en yüksek etkiyi gösteren medya faktörü, diğer meslek gruplarında da etkili olduğunu göstermektedir. 
2014 Ankara yerel seçimlerinde parti lideri faktörünün...

\subsubsection{Katılımcılarda Oy Vermeyi Etkileyen Siyasal Tutum ve Davranışlar}

\begin{tabular}{|c|c|c|c|c|c|c|c|c|c|}
\hline & 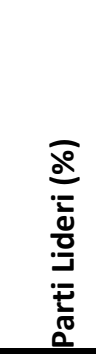 & 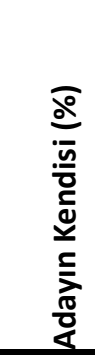 & 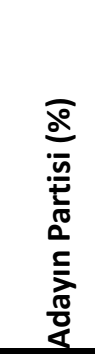 & 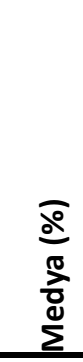 & 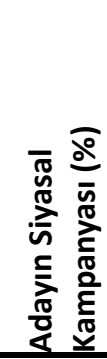 & 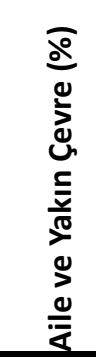 & 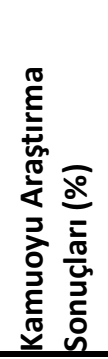 & 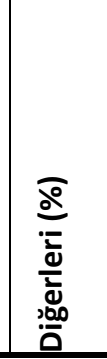 & $\begin{array}{l}\frac{\varepsilon}{\pi} \\
\frac{0}{0} \\
\stackrel{0}{0}\end{array}$ \\
\hline \multicolumn{10}{|c|}{ Oy Verilen Parti $\left(X^{2}=165,822 s d=12 p=, 000<0,01\right)$} \\
\hline AK Parti & 59,5 & 10,3 & 13,1 & 1,2 & 1,2 & 3,2 & 1,2 & 10,3 & 100,0 \\
\hline $\mathrm{CHP}$ & 13,3 & 42,3 & 25,0 & 4,4 & 4,0 & 1,6 & 3,2 & 6,2 & 100,0 \\
\hline $\mathrm{MHP}$ & 13,0 & 28,6 & 33,8 & 3,9 & 6,5 & 5,2 & 2,6 & 6,4 & 100,0 \\
\hline İşçi Partisi & 41,2 & 32,4 & 5,9 & 11,8 & 5,9 & 2,9 & 0 & 0 & 100,0 \\
\hline HDP & 25,0 & 25,0 & 50,0 & 0 & 0 & 0 & 0 & 0 & 100,0 \\
\hline BBP & 0 & 25,0 & 50,0 & 0 & 0 & 0 & 0 & 25 & 100,0 \\
\hline Yurt Partisi & 33,3 & 0 & 0 & 0 & 0 & 0 & 33,3 & 33,4 & 100,0 \\
\hline Saadet Partisi & 66,7 & 0 & 0 & 0 & 0 & 33,3 & 0 & 0 & 100,0 \\
\hline \multicolumn{10}{|c|}{$\left(X^{2}=92,986 s d=24 P=, 000<0,01\right)$} \\
\hline Radikal Sol & 18,9 & 18,9 & 29,7 & 8,1 & 2,7 & 2,7 & 10,8 & 8,2 & 100,0 \\
\hline Merkez Sol & 17,3 & 30,0 & 39,1 & 1,8 & 3,6 & 0,9 & 2,7 & 4,6 & 100,0 \\
\hline Merkez Sağ & 48,7 & 20,2 & 17,1 & 1,0 & 1,6 & 2,6 & 1,6 & 7,2 & 100,0 \\
\hline Radikal Sağ & 39,6 & 22,8 & 19,8 & 1,0 & 5,0 & 5,0 & 3,0 & 3,8 & 100,0 \\
\hline Hiçbiri & 22,4 & 37,7 & 12,8 & 6,4 & 3,2 & 3,2 & 0,6 & $\begin{array}{l}13, \\
7 \\
\end{array}$ & 100,0 \\
\hline \multicolumn{10}{|c|}{ Parti Bağ|ılığı $\quad\left(X^{2}=106,750 s d=16 p=, 000<0,01\right)$} \\
\hline Çok Zayıf & 20,3 & 45,9 & 6,8 & 2,7 & 4,1 & 5,4 & 2,7 & $\begin{array}{l}12, \\
1\end{array}$ & 100,0 \\
\hline Zayıf & 23,3 & 30,2 & 14,0 & 11,6 & 2,3 & 2,3 & 2,3 & 14 & 100,0 \\
\hline Orta Düzey & 15,9 & 43,4 & 10,6 & 7,1 & 5,3 & 6,2 & 3,5 & 8 & 100,0 \\
\hline Güçlü & 36,9 & 20,4 & 26,2 & 1,0 & 5,8 & 2,9 & 2,9 & 3,9 & 100,0 \\
\hline Çok Güçlü & 43,1 & 16,1 & 28,8 & 0,7 & 0,7 & 0,7 & 1,5 & 8,4 & 100,0 \\
\hline \multicolumn{10}{|c|}{ Oy Verme Karar Zamanı $\left(X^{2}=154,078=16 p=, 000<0,01\right)$} \\
\hline Baştan Belli & 42,1 & 15,7 & 27,0 & 1,4 & 1,4 & 3,0 & 1,7 & 7,7 & 100,0 \\
\hline $\begin{array}{l}\text { Adaylar } \\
\text { belirlendiğinde }\end{array}$ & 19,7 & 59,1 & 6,8 & 2,3 & 3,8 & 0 & 3,0 & 5,3 & 100,0 \\
\hline $\begin{array}{l}\text { Kampanya } \\
\text { Ortalarında ortasında }\end{array}$ & 10,8 & 18,9 & 27,0 & 13,5 & 13,5 & 5,4 & 5,4 & 5,5 & 100,0 \\
\hline Son Bir Haftada & 23,1 & 17,9 & 17,9 & 12,8 & 5,1 & 7,7 & 2,6 & $\begin{array}{l}12, \\
9\end{array}$ & 100,0 \\
\hline Sandık başında & 13,8 & 37,9 & 10,3 & 0 & 3,4 & 3,4 & 3,4 & 27,8 & 100,0 \\
\hline
\end{tabular}

\subsubsection{Oy Vermeyi Etkileyen Değişken ve Oy Verilen Parti İlişkisi}

Oy vermeyi etkileyen değişkenler açısından üç büyük parti için oy verilen parti değerlendirildiğinde, AK Parti’ye oy verenlerin yüzde 59,5'i parti lideri 
2014 Ankara yerel seçimlerinde parti lideri faktörünün...

faktöründen etkilendiğini ortaya koymaktadır. Bu oran CHP'de yüzde 13,3, MHP'de 13,0'dır. Üç parti lider faktörü açısından, oy vermede etmen olarak değerlendirildiğinde, AK Parti'nin bir lider partisi olduğu, CHP ile MHP'de lider faktörünün siyasal anlamda çok zayıf olduğu söylenebilir. Hatta bu partilerde oy verme nedenleri açısından lider sorunu olduğu bile söylenebilir.

Oy vermede en önemli faktör olarak aday unsuru yüzde 42,3 ile CHP'de ön plana çıkarken MHP'de 33,8 ile parti faktörü ön plana çıkmaktadır. Oy vermeyi etkileyen değişkenler ve oy verilen parti arasında yapılan karşılaştırmada anlamlı bir farklılık vardır $\left(\mathrm{X}^{2}=165,822 \mathrm{sd}=12 \mathrm{p}=, 000<0,01\right)$.

\subsubsection{Oy Vermeyi Etkileyen Değişken ve Siyasal Eğilimler iliş̧kisi}

Siyasal eğilimlere göre oy verme tercihindeki etkili değişkenler incelendiğinde; merkez sağ seçmenin yüzde 48,7'si ve radikal sağ seçmenin yüzde 39,6'sı oy verme kararında parti liderini etkili bulmaktadır. Merkez sol seçmenin yüzde 30'u ve hiçbir siyasal kimliğe sahip olmayan seçmenin yüzde 37,7'si oy verme kararında adayın kendisini ve merkez sol seçmenin yüzde 39,1'nin oy verme kararında adayın partisini daha etkili görmektedir.

Sonuçların da açıkça ortaya koyduğu gibi hiçbir siyasal eğilime bağlı olmayan seçmen katılımcılar, diğer siyasal eğilim kategorilere göre oy tercihini şekillendirmede adayın kendisine verdikleri önem açısından daha yüksek oranlara sahipken, merkez ve radikal sağ seçmen parti liderini ön planda tutmaktadır. Buna karş1lık merkez sol seçmen adayın partisine önem vermektedir. Söz konusu çapraz tablonun ki-kare analiz sonuçları da incelenmiş ve bu farklılaşmanın anlamlı olduğu ortaya konmuştur $\left(X^{2}=92,986 s d=24 P=, 000<0,01\right)$.

\subsubsection{Oy Vermeyi Etkileyen Değişken ve Parti Bağlılığı ilişkisi}

Katılımcıların parti bağlılığı ile oy vermede etkili olan değişkenler arasında anlamlı bir ilişki bulunmaktadır $\left(X^{2}=106,750 s d=16 p=, 000<0,01\right)$. Sonuçlar incelendiğinde; parti bağlılığı çok zayıf olanların yüzde 45,9'u zayıfların 30'si, orta 
düzey parti bağlılığına sahip olanların yüzde 43,4'ü parti bağl1lı̆̆ güçlü olanların yüzde $20^{\prime}, 4$ 'ü ve çok güçlülerin yüzde $16,1^{\prime}$ i adayın kendisini oy vermede etkili görmektedir. Buna göre katılımcıların bir partiye olan bağlılıkları zayıfladıkça, oy vermede adayın kendisini etkili bulma eğilimleri artış göstermektedir.

Adayın partisi kategorisi ise, parti bağlılığı çok zayıf olanların yüzde 6,8, zayıfların yüzde 14'ü, parti bağlılığ güçlü olanların yüzde 26,2'si ve çok güçlülerin yüzde 28,8 'i tarafından önemli görülmektedir. Diğer yandan, parti bağl1lığı çok zayıf olanların yüzde 20,3'ü, zayıf olanların yüzde 23,3'ü, güçlü olanların yüzde 36,9'u ve çok güçlü olanların yüzde 43,1'i oy verme kararlarında parti lideri olgusunu etkili bulmaktadırlar. Betimleyici istatistik sonuçları; insanların bir partiye olan parti bağlılıkları arttıkça, oy vermede adayın partisini etkili bulma eğilimlerinin artış gösterdiğine işaret etmektedir.

\subsubsection{Oy Vermeyi Etkileyen Değişken ve Oy Verme Karar Zamanı iliş̧kisi:}

Araştırmaya katılanların oy verme karar zamanları ile oy vermede etkili olan değişkenler arasında anlamlı bir ilişki dikkati çekmektedir $\left(X^{2}=\mathbf{1 5 4 , 0 7 8}=16\right.$ $\boldsymbol{p}=, 000<0,01$ ). Ortaya çıkan sonuçlara bakıldığında; seçim öncesinde hangi partiye oy vereceği belli olanların yüzde 42,1 'i, oy verme kararında parti liderini, adaylar belirlendiğinde oy verme kararını belirleyenlerin yüzde 59,1'i aday faktöründen etkilendiğini, kampanya ortalarında oy verme kararını belirleyenlerin yüzde 27'si oy verme kararında adayın partisi faktörünü etkili bulurken, son bir haftada kararını verenlerin yüzde 23,1'i parti liderini, 17,9'u adayı ve partiyi, 12,8'i medyayı etkili bulmaktadır. Oy verme kararını sandık başında belirleyenlerin yüzde 37,9'u adayın kendisinden, yüzde 13,8 'i parti liderinden, yüzde 10,3' adayın partisinden etkilendiklerini söylemişlerdir.

Buna göre katılımcılar arasında yerel adaylar belirlendiğinde ve sandık başında siyasal karara varanlar, diğer kategorilere göre bir yerel seçimde adayın kendisini oy vermede daha etkili görürlerken, oy verme kararı baştan belli olanlar ve seçimlere bir hafta kala kararını verenlerin parti liderinden etkilendikleri görülmektedir. 


\section{Tartışma ve Sonuç}

Yapılan teorik ve ampirik bilimsel çalışmalar ile güncel siyasal yaşamdaki uygulamalarda, siyasal parti liderliği olgusunun; temsil etme, tanıtma ve seçmenin oy vermesini etkileyen en önemli faktörlerden birisi olduğu görülmüştür. Siyasal parti liderliği konusu; liderin var olan kişisel ve siyasal hasletlerinin üzerine, yasal yetkilerle birlikte profesyonel siyasal iletişim danışmanları, kitle iletişim araçları teknolojileri ve medyanın desteği ile inşa edilen, siyasal kimlik, siyasal imaj ve siyasal itibarın somut olarak sembolleştirildiği en önemli siyasal değerdir. Bu değer siyasal iletişim açısından zihinsel olarak seçmenle sürekli iletişim halindedir.

Bir partiye oy vermede veya vermemede seçmeni en çok etkileyen faktörün parti lideri olduğu birçok çalışmada ortaya konmuştur. Bu durum, çalışmanın teorik kısmında yer alan literatürdeki araştırma sonuçları ve bulgularda görülmektedir. Ayrıca yapılmış olan bu saha çalışması ile 2014 Ankara yerel seçimlerinde parti lideri faktörünün seçim sonuçlarına etkisi de ortaya konmuştur. Bu durumun Ak Parti'de lehte, CHP ve MHP'de aleyhte bir sonuç doğurduğu tespit edilmiştir. Çünkü yapılan araştırmada; oy vermeyi etkileyen parti lideri faktörü, AK Parti’ye oy verenlerde; \% 59,5 etkili olurken, aday ve parti faktörü \% 10’larda kalmış, adayın seçim kampanyası ve diğer faktörler çok etkili olamamıştır. Buna karşılık CHP'ye oy verenlerde; parti lideri faktörü sadece \% 13,3 etkili olabilmiş, adayın kendisi faktörü \% 42,3 ve parti faktörü \% 25 ile baskın faktörler olmuştur. MHP’ye oy verenlerde ise; parti lideri faktörü \% 13, aday faktörü \% 28,6 ve parti faktörü \% 33,8 oranında etkili olmuştur.

Araştırmada; Türk seçmeninin önemli bir kısmının oy verdiği partiye, adaya ve parti liderine bağl1lık düzeylerinin ortalamanın üstünde olduğu, 10 üzerinden yapılan değerlendirmede 7 civarında aritmetik ortalamaya sahip olduğu tespit edilmiştir.

Araştırmada, demografik özellikler ile oy vermeyi etkileyen değişkenler açısından önemli bulgular elde edilmiştir. Bunlardan ilki, oy vermeyi etkileyen parti lideri faktörünün erkeklerin oy vermesinde kadınlara göre daha fazla etkili olduğudur. 
İkincisi, seçmenin yaşı ile parti lideri ve partiye bağlılık düzeyleri arasında doğrusal bir ilişkinin olduğudur. Seçmenin yaşı arttıkça parti liderine ve partiye bağlılık düzeyi de artmaktadır. Buna karşılık seçmenin eğitim düzeyi ile oy verme kararında etkili olan faktörlerden parti ve parti lideri bağlılı̆̆ı arasında negatif bir ilişki vardır. Yani seçmenin eğitim düzeyi arttıkça parti ve lidere bağl1lık düzeyi azalmakta buna karş1lık adaya bağlılık düzeyi yükselmektedir. Üçüncü olarak seçmenin aylık ortalama gelir düzeyi ile parti liderine bağlılık düzeyi arasında anlamlı bir ilişki tespit edilmiştir. Buna göre; seçmenin gelir düzeyi arttıkça parti liderine bağl1lık düzeyi de artmaktadır. Son olarak demografik özelliklerden esnaf, serbest meslek, emekli, sanayici ve ev hanımı meslek mensupları ile parti liderine bağlılık arasında anlamlı bir ilişkinin olduğu tespit edilmiştir. Buna göre; sözü edilen meslek mensuplarından sanayicinin \% 72,7'sinin, ev hanımlarının \% 48,8'nin, serbest mesleğin \% 38,6'sının, emeklinin \% 35,8'nin ve esnafın yüzde \% 34,3'nün, oy verme kararlarında parti lideri faktörünün etkili olduğu tespit edilmiştir.

Araştırmada, seçmenin siyasal eğilimleri ile oy vermeyi etkileyen faktörler karşılaştırmasında; siyasal düşünce olarak sol eğilimli seçmende parti ve adaya bağlılık düzeyinin yüksek olmasına karşılık lidere bağlılık düzeyinin zayıf olduğu, buna karşılık să̆ eğilimli seçmende lidere bağlılık düzeyinin yüksek olmasına karşılık parti ve adaya bağlılık düzeyinin zayıf olduğu görülmüştür.

Araştırmada katılanların oy verme karar zamanlarına bakıldığında; yarıdan fazlası olan yüzde 60,5'inin seçim öncesi, yüzde 22'sinin adaylar belirlenince, yüzde 6,2'sinin kampanya ortalarında, yüzde 6,5'nin seçimlere bir hafta kala, yüzde 4,8'nin sandık başında oy verme kararını belirlediği ortaya çıkmıştır. Özellikle oy verme kararını son bir haftada ve sandık başında belli eden kararsız seçmen ya da yüzer-gezer seçmen olarak adlandırılan seçmen tipinin seçimlerin kaderini tayin edebilecek sayısal yeterliliğe sahip olduğu görülmektedir. Nitekim bu durum 2014 Ankara Büyükşehir Belediye Başkanlığı seçimlerinde kazanan ve kaybeden tarafın arasındaki oy farkının \% 1,1 olduğu gerçeği ile birlikte değerlendirildiğinde sonucu belirleme açısından bire bir örtüşmektedir.

Araştırmada; Türk seçmeninin oy verme kararında sırasıyla; parti lideri, aday ve parti faktörlerinin en önemli faktörler olduğu, diğer faktörlerin sınırlı da olsa seçmeni etkilediği ortaya çıkmıştır. 
2014 Ankara yerel seçimlerinde parti lideri faktörünün...

Bu çalışmada, seçmenin oy verme kararında "parti lideri” faktörünün etkisi ortaya konmaya çalışılmış ve bu anlamda; saha araştırmasından soyut teorik bilgileri destekleyici somut veriler elde edilerek önemli bir boşluk doldurulmuştur. Yapılan araştırmada ortaya çıkan veriler bu faktörün seçim sonuçlarını belirleyici rol oynadığını göstermiştir. Bundan böyle, bu konu ile ilgili yapılacak çalışmalarda "parti lideri faktörünün hangi şartlarda ve niçin etkili olduğu?” sorularına cevap arayacak siyasal sosyolojik ve siyasal psikolojik bakış açılarına ihtiyaç duyulmaktadır.

\section{KAYNAKÇA}

DAMLAPINAR, Zülfikar; BALCI, Şükrü (2014). Siyasal İletişim Sürecinde Seçimler, Adaylar, İmajlar, Konya: L-T (Litera Türk Academia) Yayını.

DİNÇER, Müjde Ker; BİTİRIM, Selim (2007). "Kurum Kültürü çalışmalarında Hizmetkar Liderlik Anlayışı ile Değer Yaratmak”, İstanbul Üniversitesi, İletişim Fakültesi Dergisi, Sayı: 27, 60-72.

DUVERGER, Moris (1984). Politikaya Giriş, (Çev: Sami Tiryakioğlu), İstanbul: Varlık Yayınları.

DOĞAN, Adem; GÖKER, Göksel (2010). "Yerel Seçimlerde Seçmen Tercihi (29 Mart Yerel Seçimleri Elazı̆̆ Seçmeni Örneği)”, Eskişehir Osmangazi Üniversitesi İIBF Dergisi, 5(2), 159-187.

EKİNCİ, Necdet (2014) "Siyasal İletişim Çalışmalarında Kapsam ve Yaklaşım Sorunsalı", İ\&D İLETİŞİM ve DİPLOMASİ, Sayı: 3, 5-24.

ERZEN, Meltem Ünal (2008). “Siyasi Lider İmajlarının Seçimlerde Etkisi”, İstanbul Üniversitesi, İletişim Fakültesi Dergisi, Sayı: 31, 65-80.

GÜLLÜPUNAR, Hasan; DİKER, Ersin; ASLAN, Emre S. (2013). “Oy Verme Yaklaşımları Bağlamında Aday Merkezli Seçmen Tercihi Üzerine Deneysel Bir Araştırma”, İktisat ve Girişimcilik Üniversitesi, Sosyal Bilimler Enstitüsü, Akademik Bakış Dergisi, Sayı: 35. Mart-Nisan 2013. GÜLLÜPUNAR, Hasan (2010). Siyasal İletişim ve Aday İmajı, Konya: Eğitim Akademi. 
HÜLÜR, Himmet; KALENDER, Ahmet (2003). Sosyo-Politik Tutumlar ve Din (Konya Araştırması), Konya: Çigi Kitapevi Yayınları.

KAID, Lynda Lee; BACHA, Holtz Christina. (2008), Encyclopedia of Political Communication, Vol:2, California: Sage Publications.

KALENDER, Ahmet (2000). Siyasal İletişim: Seçmenler ve İkna Stratejileri, Konya: Çizgi Kitapevi.

KALENDER, Ahmet (2005). Siyasal İletişim: Seçmenler ve İkna Stratejileri, Konya: Çizgi Kitapevi.

KIŞLALI, Ahmet Taner (1987), Siyaset Bilimi, Anara Üniversitesi, Basın Yayın Yüksekokulu Yayınları.

KESKİN, Fatih (2014). Politik İletişim Sözlügü, Ankara: İmge Kitapevi.

KILIÇASLAN, Çakmak Emine (2011). Siyasal İletişim-İdeoloji ve Medya İlişkisi, İstanbul: Kriter Yayınları.

KÖZLEME, Olgun (2013). "Liderlik, Siyasal Otorite Tipleri ve Karizma”, Toplum Bilimleri Dergisi, Ocak-Hairan, 239-250.

POLAT, Cihat, GÜRBÜZ, Esen, İNAL, M. Emin (2004). Hedef Seçmen: Siyasal Pazarlama Yaklaşımı, Ankara: Nobel Yayınları.

ÖCAL, Hülya; ÖZMEN, Alpaslan; TOPÇU, Birol (2011). "Siyasal Pazarlama Faktörlerinin, Seçmen Eğilimleri Üzerindeki Etkileri” (Afyon Araştırması) E-Journal of New World Sciences Academy, 6:4, 400-421.

ÖZKAN, Abdullah (2004). Siyasal İletişim, İstanbul: Nesil Yayınları.

ÖZKAN, Necati (2007). Seçim Kazandıran Kampanyalar, İstanbul: Mediacat Yayınları.

ÖZEL, Zühal (2009). “Siyasal Lider İmajları: Gerçekliğin Yeniden Üretilmesi”. Siyasetin İletişimi (Editör), Abdullah Özkan, İstanbul: Tasarım Yayınları, 169-191.

ŞİMŞEK, M.Ş.; AKGEMCİ, T.; ÇELİK, A. (2001). Davranış Bilimlerine Giriş ve Örgütlerde Davranış, Ankara: Nobel yayınları.

YALIN Eroğlu, Bahar (2012). “Siyasal Liderliği “Duygusal” Düşünmek”: Siyasal Parti Liderlerinin Üniversite Gençliği Üzerindeki Duyusal Zeka Algısı, Karadeniz Araştırmaları, 2012-Güz, Sayı: 35, 81-99. 
2014 Ankara yerel seçimlerinde parti lideri faktörünün...

UZTUĞ, Ferruh (1999). Siyasal Marka/Seçim Kampanyaları ve Aday İmajı, Ankara: MediaCat Yayınları.

YILDIZ, Nuran (2002). Türkiye'de Siyasetin Yeni Biçimi: Liderler, İmajlar, Medya, Ankara: Phoenix Yayınları.

ZEL, Uğur (2011). Kişilik ve Liderlik, 3.baskı, Ankara: Nobel Yayınları.

Elektronik yayınlar:

https//www.Milliyet.om.tr-erdoğan çarpıcı bir zafer kazandı-/siyaset/detay (Erişim tarihi; 20.01.2015). 